\title{
Nasıl Bir Çevre Eğitimi? Çağdaş Yaklaşımlar Çerçevesinde Bazı Öneriler
}

\author{
What Kind of Environmental Education? Some Suggestions in the Context of Contemporary \\ Approaches
}

\author{
Ali Ekber Gülersoy* ${ }^{*}$ İlknur Dülger ${ }^{* *}$ - Elif Dursun ${ }^{* * *}-$ Damla Ay $^{* * * *}$ - Duygu Duyal ${ }^{* * * * *}$
}

\begin{abstract}
One of the most important common problems in the world is that people benefit from nature unlimitedly and in this way they cause serious environmental damages. That the environmental problems have reached serious levels in recent years has led people to find solutions in this regard. In order to protect the environment, individuals with high environmental awareness and environmental sensitivity should be raised. Education is necessary for people to be conscious about a topic or an event. Developing environmental awareness in the society and gaining the necessary environmental sensitivity and responsibility to individuals can only be possible with an effective environmental education. In the present, the complexity of environmental problems and the increase in their impact areas have led to the questioning of the adequacy of the existing environmental education. For this reason, there is a search for new and contemporary environmental education approaches that can meet the needs of the society by producing solutions to existing environmental problems in recent years and scientists are constantly proposing new approaches to the environmental education. In this study, firstly we addressed the development process of the environmental education in the world and in Turkey. Then, the content, features and deficiencies of environmental education in the Primary, Secondary Education Curriculum and non-formal education in our country were evaluated. Subsequently, the approaches used in environmental education were examined and
\end{abstract}

\footnotetext{
* Doç.Dr., Dokuz Eylül Üniversitesi, Buca Eğitim Fakültesi, Sosyal Bilgiler Eğitimi

Assoc.Prof. Dr., Dokuz Eylul University, Buca Faculty of Education, Social Studies Education

ORCID 0000-0003-0338-1366

gulersoy74@gmail.com

*** Dr., Yüksek Lisans Öğrencisi, Dokuz Eylül Üniversitesi, Eğitim Bilimleri Enstitüsü, Çevre Eğitimi Anabilim Dalı

Dr., M.A. Student, Dokuz Eylul University, Institute of Educational Sciences, Department of Environmental Education

ORCID 0000-0003-3434-8702

ilknurd1984@hotmail.com

**** Yüksek Lisans Öğrencisi, Dokuz Eylül Üniversitesi, Eğitim Bilimleri Enstitüsü, Çevre Eğitimi Anabilim Dalı M.A. Student, Dokuz Eylul University, Institute of Educational Sciences, Department of Environmental Education ORCID 0000-0003-2073-5613

elif_dursun012@hotmail.com

***** Yüksek Lisans Öğrencisi, Dokuz Eylül Üniversitesi, Eğitim Bilimleri Enstitüsü, Çevre Eğitimi Anabilim Dalı M.A. Student, Dokuz Eylul University, Institute of Educational Sciences, Department of Environmental Education ORCID 0000-0002-6508-5530

damla-ayy@hotmail.com

****** Yüksek Lisans Öğrencisi, Dokuz Eylül Üniversitesi, Eğitim Bilimleri Enstitüsü, Çevre Eğitimi Anabilim Dalı M.A. Student, Dokuz Eylul University, Institute of Educational Sciences, Department of Environmental Education ORCID 0000-0003-4997-6808
}

duyguduyal.41@gmail.com

Cite as/ Atıf: Gülersoy, A. E., Dülger, İ., Dursun, E., Ay, D. \& Duyal, D. (2020). $\quad$ Nasıl $\quad$ bir $\quad$ çevre eğitimi? Çağdaş yaklaşımlar çerçevesinde bazı öneriler. Turkish Studies, 15(5), 2357-2398. https://dx.doi.org/10.7827/TurkishStudies.44074

Received/Geliș: 07 June/Haziran 2020

Accepted/Kabul: 25 August/Ağustos 2020

Copyright $($ ) MDE, Turkey

Checked by plagiarism software

Published/Yayın: 31 August/Ağustos 2020

CC BY-NC 4.0 
suggestions were given about the features that a qualified environmental education should have. It is our hope that the research will contribute to determining the qualifications of an inclusive and holistic environmental education approach in the light of contemporary approaches and creating awareness about the value of environmental education.

Structured Abstract: Introduction: There is a continuous exchange between all creatures and their environments in ecosystem. Also human is within this cycle as from one's existence since one is a part of nature. Humanbeing, by one's nature, is a social being and needs to live within a society. Transition to social life has brought along a lot of hitches for environment.

Particularly, technology which developed after industrial revolution; growing population; and therefore increasing production and consumption have increased also damage to environment. Increasing in environmental problems remarkably directed people to solution seeking on this issue, and environmental problems and solutions have begun to be discussed across the world. It is possible only with education for people to become conscious on this issue. In this context, it is thought that environmental education is the most important instrument in raising individuals with a high environmental consciousness and with a positive attitude and behaviour toward environment. How an effective and qualified environmental education should be has been discussed for long years. Particularly, implementation of traditional teaching methods at which teacher is active and student is included as listener only in formal education institutions decreases efficiency from education (Bulut, 2015; Demir \& Yalçın, 2014).

It is very difficult for classical education methods to be enough on this issue since educational education, by its nature, is a learning domain that needs discovering by experience and practice. In order for environmental education to reach its targets, there is a need for a education that includes innovative learning methods nested with nature, such as 'through invention and discovery', with quality that would contribute to the individual's cognitive domain, attitudes and values toward environment, For this reason, when it comes to environmental education, it is necessary to head/turn towards contemporary teaching methods and techniques by steering away from traditional teaching methods.

In present day, it is seen that scientists are continuously putting forward suggestions for approaches to new environmental education with the purpose of increasing efficiency from environmental education. In line with the adopted approach, priority targets and functions of environmental education being implemented can differ from (Özdemir, 2007; Y1lmaz, 2016).

In these times when damage to environment has reached global scale increasing gradually, future generation's education about environment and environmental problems has become highly important situation. Current situation reveals necessity of gaining a comprehensive study/work of how an effective environmental education to fulfill the needs at the present time should be to the literature.

\section{Purpose and Method}

In this study, we benefitted from qualitative descriptive analysis method. Descriptive analysis is a method that is carried out in the way that data obtained about the specified subjects are processed\&organized and cause-effect relationships between them are examined\&presented as well as making some predictions and interpretations for future by interpreting these data (İlhan, Gülersoy \& Gülersoy, 2017; Y1ldırım \& Şimşek, 2000).

In the first stage of the study, we addressed which phases the environmental education in world and Turkey has gone through and to what degree it has reached by making literature reviews, and then we gave a place to examination of course achievements of environmental education in primary and secondary education in our country. In the final stage, we addressed environmental education in the light of contemporary approaches and made some recommendations for how an environmental education should be conducted in our country.

With the said study, we aimed at contributing to qualities of a comprehensive and an effective approach to environmental education that could meet ever-changing needs of society.

\section{Results}

Results of the study include those headings; A General Outlook on Environmental Education in the world and Turkey; Environmental Education in Primary, Secondary and High School Curricula (in Formal Education); Environmental Education in Non-Formal Education; Contemporary Approaches in Environmental Education; What Kind of Environmental Education?

In chapter of results of the study, we examined (on unit basis) courses which gave a place to achievements of environmental education in primary and secondary education curricula and we stated achievements which are expected for students to gain in the end of units. Later, we addressed current situation of environmental education in non-formal education. Following examination of curricula of 
educational institutions, we gave in headings of approaches which have been implemented in environmental education during process from the past to the present and which are still being implemented, and we mentioned positive and negative points of each approach. We stated that approach to environmental education of a developed society should be conveyed within a multi-perspective understanding not only with science dimension but also with psychological, political, legal, sociological, technological, philosophical, educational and cultural ones. Under the heading 'What kind of environmental education', we tried to draw general framework of an environmental education with the quality that could meet requirements of the developed societies

\section{Discussion, Conclusion and Recommendations}

In the present day, it has been accepted that individuals are needed, with the improved (raised) environmental awareness for struggle with environmental problems, and with a positive attitude toward environment. When it comes to environmental awareness (consciousness), value of environmental education reveals, which would be able to make the young, who will be at the head of a lot of important occupational groups in the future, raise as individuals with high environmental sensitivity.

In conclusion chapter of the study, we stated that an effective environmental education would not be possible with traditional methods; it should be given only within a system in which student is active and the student learns through experience and practice; and this is promoted by many researchers (Aktepe \& Temur, 2018; Bilgi 2008; Dinçer, 1988; Özay Köse, 2010; Ozaner, 2004; Özdemir, 2007). We also mentioned that; giving achievements of environmental education in a limited way by integrating into other courses instead of teaching them within a separate course for environmental education exclusively in current curricula reduced the effect of environmental education; and that this situation was supported by many previous studies (Bulut, 2015; Demir \& Yalçın, 2014; Erdoğan, Bahar \& Uşak, 2012). In the final stage, in the light of results of the study, we made some recommendations for a comprehensive, contemporary and effective environmental education (Bulut, 2015; Demir \& Yalçın, 2014; Erdoğan, Bahar \& Uşak, 2012).

In the light of data obtained, it is recommended to pay attention to these issues so that efficiency in environmental education should be increase;

-Environment should be made to address as a whole not only on science dimension, but also consisting of a lot of natural, artificial, social, economical, cultural, political, technological, ethical, historical, psychological and aesthetical elements in the environmental education.

-Environmental education should consist innovative learning processes, such as 'through invention and discovery' etc., which will help students construct various ways of cognition, behaviour and emotion. Student-centered approach should replace the teaching, based on rote in environmental education, in which teacher is active but student is passive, and which is carried out as reading and lecturing only.

-A method should be made to follow that is entertaining, doesn't bore students, remarkable, puts emphasis on the agenda and that benefits from the written and visual media, by steering away from repetition in achievements and activities of environmental education of which main objective is to raise environmental awareness and to generate permanent behavioral change (Kalıpçı, Öztaş \& Özdemir, 2010; Uzun \& Sağlam, 2007; Y1lmaz, Morgil, Aktuğ \& Göbekli, 2002).

-Environmental education should be addressed as a whole but not by adding into other curricula or giving in the background under category of elective course, and it should be taught as compulsory course under the course 'Environmental Education' in all stages of education and at all class levels.

-A new approach to environmental education should be adopted that uses 'sustainability in the nature' point of view as base by taking contemporary approaches into account, and curricula of the course 'environment' should be rearranged in line with the adopted approach (Muşlu Kaygısız, 2020).

-Techniques should be brought tho the fore that would make students learn through experience in the environmental education, internalize what they have learned and put them into practice. For this purpose; a place should be given to methods and techniques of active teaching, such as on-site examination, nature camps, project studies, observation, argumentation, learning cycle, brainstorming, group work, visual and animation works and role play etc.

-Environmental education should be maintained for life-long beginning at an early age within the scope of all formal and non-formal education, and positive attitude and behaviour as well as knowledge acquisition should be generated on individuals. Environmental education should not be seen as an only course and environmental awareness should be raised to people of all ages.

-Partially all disciplines should be benefitted in environmental education and an interdisciplinary approach should be followed integrating these sections balancedly. 
-Skills such as problem-solving, critical thinking and environmental literacy etc. should be tried to give to students in a way that would be suitable for all age groups.

-Some arrangements which necessitate these in programmes should be made so that students should attend conferences and seminars on environment, watch regularly documentaries or movies concerning the subject and should take an active role in non-governmental organizations.

-At the bottom of environmental insensitivity, ethical problems lie. Accordingly, a place should be given to activities that would make individuals mature on moral grounds for the purpose of adopting environmental values. In addition to these, an approach to environmental ethics should be developed that would also be able to direct environmental education in the light of interdisciplinary academic studies, being pertain to Turkey and with universal content.

-Not only students' immediate surroundings but also environmental problems across all the world should be taught/told to students due to environmental problems are influential generally on global scale but not on a small scale, and students should be made to obtain large-scale thinking skill.

-It is not possible for a person who doesnt have competence on a subject to teach this subject to someone else. For this reason, in-service trainings and seminars should be organized for teachers who would teach/told the course 'environmental education' in all teaching stages beginning from pre-school period. Current teachers should be made to follow continuously academic studies which are carried out in this field, and if possible, teachers should be encouraged to get a master's degree in their fields.

- The number of studies carried out for this situation is very limited, future and development of environmental education in our country. Different points of view to the subject should be brought forward increasing academic studies about this subject.

Keywords: environmental education, contemporary approaches, education curriculum, environmental problems, environmental consciousness

Öz: Dünyadaki en önemli ortak sorunlardan birisi insanların doğadan sınırsız olarak yararlanmaları ve bu sırada ciddi çevresel hasarlara neden olmalarıdır. Son yıllarda çevresel sorunların ciddi boyutlara ulaşması insanları bu konuda çözüm arayışına yönlendirmiştir. Çevrenin korunması için çevresel bilinci ve çevresel duyarlılığı yüksek bireylerin yetiştirilmesi gerekmektedir. İnsanların bir konu ya da olay hakkında bilinç sahibi olmaları için eğitim gereklidir. Toplumdaki çevre bilincinin geliştirilmesi, bireylere gerekli çevre duyarlılığı ve sorumluluğunun kazandırılması ise ancak etkili bir çevre eğitimi ile mümkün olabilir. İçinde bulunduğumuz dönemde, çevre problemlerinin karmaşıklaşması ve etki alanlarının artması, mevcut çevre eğitiminin yeterliliğinin sorgulanmasına neden olmuştur. Bu nedenle özellikle son yıllarda mevcut çevresel sorunlara çözüm üreterek, toplumun ihtiyaçlarına cevap verebilecek nitelikte yeni ve çağdaş çevre eğitimi yaklaşımları arayışı söz konusudur ve bilim insanları sürekli olarak çevre eğitimine yönelik yeni yaklaşımlar önermektedirler. Bu çalışmada; ilk olarak dünyada ve Türkiye'de geçmişten bu yana çevre eğitiminin gelişim süreci ele alınmıştır. Ardından ülkemizde İlkokul, Ortaokul ve Ortaöğretim Öğretim Programları'ndaki ve yaygın eğitimdeki çevre eğitiminin içeriği, özellikleri ve eksiklikleri değerlendirilmiştir. Daha sonra çevre eğitiminde yararlanılan yaklaşımlar incelenerek, nitelikli bir çevre eğitiminin sahip olması gereken özellikler hakkında önerilere yer verilmiştir. Araştırmanın çağdaş yaklaşımlar ışı̆̆ında kapsayıcı ve bütüncül bir çevre eğitimi yaklaşımının niteliklerini belirlemeye ve çevre eğitiminin değeri hakkında farkındalık yaratmaya katkı sağlaması temennimizdir.

Anahtar Kelimeler: çevre eğitimi, çağdaş yaklaşımlar, öğretim programı, çevre sorunları, çevre bilinci

\section{Giriş}

Canlılar ile çevreleri arasında yaşamın başlangıcından bu yana kesintisiz olarak devam eden bir iletişism bulunmaktadır. Canlı ve cansız ortamın sürekli etkileşimini içeren dinamik bir sistem olan çevrede diğer tüm canlılar gibi insanın da rolü varoluşuyla birlikte başlamıştır. Başlangıçta doğadan korkan, sadece avcılık ve toplayıcılıkla yaşamını sürdüren insan Neolitik Çağ ile birlikte yerleşik hayata geçerek doğaya hükmetme, akabinde ise yaşam standartlarını yükseltebilmek amaciyla çevreden ölçüsüzce ve düşüncesizce yararlanma sürecine girmiştir (Mert, 2006; Türküm, 1998). 
İnsan, doğası gereği toplumsal bir varlıktır ve hayatını refah içinde sürdürebilmek için topluluk içinde yaşamaya ihtiyaç duymaktadır. Ancak toplumsal hayat canlılara çeşitli imkanlar vaat ederken, birtakım zorlukları da beraberinde getirmektedir. Toplumsal yaşam; gün geçtikçe sayıları çoğalan ve buna bağlı olarak gereksinimleri de giderek artan bireylerin daha ileri teknolojileri üretmelerine, barınma ve gıda gereksinimleri için geniş alanlara ihtiyaç duymalarına, bunları sağlayabilmek için yaşadıkları ortamları çoğunlukla geri dönüşü olmayacak şekilde kirletmelerine hatta doğal kaynakları yok etmelerine yol açmaktadır (Çelik ve Gülersoy, 2016; Ertürk, 2017; Gülersoy, 2014; Gülersoy, 2019a; Muşlu Kaygısız, 2020; Türküm, 1998). Özellikle 18. yüzyılda Sanayi Devrimi, endüstrileşmenin ve modern tarıma geçişin başlamasıyla birlikte nüfusta gerçekleşen hızlı artış ve teknolojik gelişmeler daha fazla üretmeyi dolayısıyla da daha fazla tüketmeyi tetiklemiş, doğanın adeta sömürülmesine varan bir tüketim sürecine girişe sebebiyet vermiştir. Üretimin bir sonucu olarak istenmeyen maddelerin açığa çıkması da kaçınılmaz olmuş ve çevresel kirlilik çok ciddi bir problem olarak gün yüzüne çıkmaya başlamıştır. Nüfus artışı düzensiz ve çarpık kentleşmeye, ayrıca birçok tarımsal alanın barınma amacıyla işgal edilmesine buna bağlı olarak da tarımda birim alandan alınan verimi arttırabilmek için koruyucu zirai gübrelerin ve ilaçların kullanılmasına yol açmıştır. Özellikle tarımsal alanlarda verim arttırma niyetiyle kullanılan maddelerin toprağa ve su kaynaklarına taşınması önemsenir derecede kirlilik sorunu ortaya çıkarmaktadır. Endüstriyel atıkların arıtılmadan direk olarak alıcı ortama bırakılması da kirliliğin boyutunu önemli derecede arttıran bir diğer faktördür (Dülger, 2018; Küçük, 2017; Öztürk, 1990; Schleicher, 1989).

Çevre sorunlarının temeline bakıldığında karşımıza insan davranışları ve değerler sistemi çıkmaktadır. Başlangıçta sadece insan ile müdahale ederek zarar verdiği doğal ortam arasındaki ilişkileri kapsayan çevre kirliliği, günümüzde artık psikolojik, politik, felsefi, hukuki, eğitimsel, sosyolojik, teknolojik ve kültürel boyutları ile çok yönlü bir kavram olarak ele alınmaktadır ve basit bir kirlilik probleminden çok daha fazlasını içermektedir. Aslında çevre problemlerinin temelinde insan davranışları ve doğal olarak insanların bu davranışlarda bulunmasına neden olan bilinç seviyeleri yatmaktadır. Bu bağlamda insanın, düşünsel ve ahlaki bilinci değişmedikçe, çevreye olan duyarlılığı da değişmeyecek ve mevcut problemler bir kısır döngü halinde devam edecektir (Atasoy, 2005; Dikicigil ve Gülersoy, 2020; Gülersoy, 2019b; Gümüş, Gülersoy ve Avc1, 2017; Pruneau vd., 2009). İnsanların bir konuda bilinçlenmesi ve sorumluluk kazanması için eğitim gereklidir. Çevre kirliliğinin önlenmesi de ancak geçmişten bu yana süregelen alışkanlıkların değiş̧irilmesi ile mümkündür. $\mathrm{Bu}$ değişim ise ancak eğitim ile sağlanabilir. İşte bu noktada ihtiyaçlara cevap verebilecek nitelikte kaliteli bir çevre eğitiminin değeri ortaya çıkmaktadır (Erten, 2003; Küçük, 2017; Ünal ve Dımışk1, 1999).

İnsanlar zaman içinde niteliğini bozdukları çevreden bekledikleri verimi sağlayamadıklarının farkına vararak, yaşam tarzlarında ve çevreye karşı olan tutumlarında yanlışlıklar olabileceğini kabul etmeye başlamışlardır. Buna bağlı olarak günümüzde insanın çevreye verdiği zarar ile çevre sorunlarının nasıl en aza indirilebileceği, yaşamsal faaliyetler sırasında çevreye nasıl daha az zarar verilebileceği giderek önem kazanan ve sorgulanan konular haline gelmeye başlamıştır. Çevre sorunlarına dikkat çekmede, önlem almada ve mevcut sorunları bertaraf etmede en etkili yol çevre eğitimi olarak kabul edilmektedir (Chawla, 1992; Görümlü, 2003).

Eğitim, canlının doğumuyla başlayan ve kapsamına bireyin ailesini, arkadaşlarını, öğretmenlerini ve çevresini de alarak devam eden uzun bir süreçtir. En yaygın kullanılan tanımına göre eğitim, insanların davranışlarında kasıtlı olarak istendik ve kalıcı olacak nitelikte değişiklikler oluşturma sürecidir (Mert, 2006; Saylan ve Karamete, 1999). Çevre eğitimi ise çevre hakkında bilgi edinilmesi, çevreye karşı olumlu tutum, düşünce ve davranışlar geliştirilmesi, bu davranışların bir yaşam tarzı haline getirilerek çevre dostu toplumlar oluşturulması süreci olarak nitelendirilebilir. Çevre eğitiminde beklenen amaç sadece çevre ile ilgili bilgi vermek değil, bireylerde çevre açısından olumlu yönde ve kalıcı olacak biçimde davranış değişikliği de sağlayabilmek olmalıdır. İlköğretimden başlayarak üniversitenin sonuna kadar planlı ve devamlı 
bir anlayışla verilecek bir çevre eğitimi, bireyleri çevreye karşı daha duyarlı hale getirirken, faydalandığı çevreye saygı duymasını, doğal döngülere zarar vermeden de yaşamını devam ettirebilmesinin mümkün olduğunu benimsetebilecek ve olumlu bir yaşam biçimi kazanmalarını sağlayacaktır. Özellikle insanların çevre konularında bilinçlenmesinin ardından nasıl bir çevre eğitiminin bütün bu gereksinimleri karşılayabileceği sorusu sıklıkla gündeme gelmeye başlamıştır (Chawla, 1992; Çolakoğlu, 2010).

Günümüz tüketim toplumunun artan ihtiyaçları karşısında, çevreye verilen zararın kümülatif olarak artması gelecek neslin çevre ve çevre sorunları konusunda eğitimini son derece önemli kılmaktadır. Mevcut durum, günümüzde gerekli ihtiyaçlara cevap verecek etkili bir çevre eğitiminin ne şekilde olması gerektiği ile ilgili kapsamlı bir çalışmanın literatüre kazandırılması gerekliliğini ortaya çıkarmaktadır.

\section{Amaç ve Yöntem}

$\mathrm{Bu}$ çalışma ile günümüz toplumunun tüm ihtiyaçlarına cevap verebilecek, kapsayıcı ve bütüncül bir çevre eğitimi yaklaşımının niteliklerine katkı sağlamak amaçlanmaktadır. Çalışma nitel türde olup betimsel analiz yöntemiyle gerçekleştirilmiştir. Betimsel analiz yönteminde, önceden sınırı belirlenmiş konular hakkında ulaşılan verilerin işlenmesi, düzenlenmesi ve özetlenmesinin ardından aralarındaki neden-sonuç ilişkilerinin irdelenip okuyucuya sunulması, ayrıca araştırmacılar tarafından yorumlanarak geleceğe yönelik bir takım tahmin ve yorumların yapılması söz konusudur (İlhan, Gülersoy ve Gülersoy, 2017; Yıldırım ve Şimşek, 2000).

Çalışmada "Günümüz koşullarında etkili ve kapsamlı bir çevre eğitimi nasıl olmalıdır?" sorusu cevaplanmaya çalışılmıştır. Çalışmanın alt problemleri ise;

"Ülkemizde ilk ve ortaögretim programlarında uygulanmakta olan çevre eğitimi gerekli yeterliliklere sahip midir?", nelerdir?"

"Ülkemizde yaygın eğitim kapsamındaki çevre eğitiminin durumu ve eksiklikleri

“Çevre Eğitimi'nde uygulanan geleneksel ve çağdaş yaklaşımların kapsam ve yeterlilik açısından farklılıkları nelerdir?"' şeklindedir.

Araştırmanın ilk aşamasını literatür taraması ile elde edilen bilgilere göre dünyada ve Türkiye'de geçmişten bu yana çevre eğitiminin gelişim süreci ile ne gibi aşamalardan geçtiği ve hangi boyuta ulaştığı oluşturmuştur. İkinci aşamada Türkiye'de ilk ve ortaöğretimde çevre eğitimi kazanımlarına yer verilen derslerin çevre eğitimine yönelik üniteleri, ünitelerin bulunduğu sınıf düzeyleri ve ders saatleri ile bu ünitelere ait kazanımlar incelenmiştir. Çalışmanın son aşamasında ise çevre eğitimi çağdaş yaklaşımlar 1şığında ele alınarak ülkemizde nasıl bir çevre eğitimi yürütülmesi gerektiği tartışılmış ve bazı önerilerde bulunulmuştur.

\section{Bulgular}

Araştırma sonucunda ulaşılan bulgular, 'Dünyada ve Türkiye'de Çevre Eğitimine Genel Bir Bakış'; 'Illkokul, Ortaokul ve Lise Öğretim Programlarında (Örgün Eğitimde) Çevre Eğitimi'; 'Yaygın Eğitimde Çevre Ĕ̈itimi'; 'Çevre Ĕ̆itiminde Çağdaş Yaklaşımlar'; 'Nasıl Bir Çevre Eğitimi?' başlıklarından oluşmaktadır.

\section{Dünyada ve Türkiye'de Çevre Eğitimine Genel Bir Bakış}

Çevre sorunlarının zaman içinde küresel boyutlara ulaşması insanların çözüm üretmede yetersiz kalmalarına yol açmaya başlamıştır. Bu durum neticesinde çevrenin korunması, iyileştirilmesi ve geliştirilmesinin ancak etkin bir çevre eğitimi aracılığıyla sağlanabileceği konusunda ortaya çıkan farkındalık, dünya çapında çevre eğitimini konu alan çalışmalara hız verilmesine neden olmuş, 70'li yıllardan itibaren ulusal ve uluslararası birçok toplantının gündeminde çevre eğitimi yer almaya başlamıştır (Çelikbaş, 2016).

Çevre eğitimine yönelik çalışmalar doğa koruma ve doğa araştırmaları şeklinde başlatılmış olup çevre eğitimi için ilk planlama ise 1970 y1lında Dünya Günü'nde gerçekleştirilmiştir. 1972 yılında Stockholm'de çevre eğitimine ve çevre sorunlarının ulaştı̆̆ küresel boyuta dikkat çekilen 
"Birleşmiş Milletler İnsan Çevresi Konferansı" gerçekleştirilmiş ve konferansın sonunda 'Birleşmiş Milletler Çevre Programı' (UNEP)'nın kurulmasına karar verilmiştir. Daha sonra 1975 yılında Stockholm Bildirisi temel alınıp Birleşmiş Milletler Çevre Programı'nın yanı sıra 'Uluslararası Çevre Eğitimi Programı' (IEEP) başlatılmıştır. 1977 yılında Tiflis'te gerçekleştirilen çevre eğitimine yönelik konferansta çevre eğitiminin ancak uluslararası iş birliği ile mümkün olabileceği belirtilerek UNESCO ve UNEP'in girişimlerinin uluslararas1 kapsamda genişletilmesinin gerekliliği kabul edilmiştir. Tiflis Konferansı'nın Bildirgesi ve Önerileri, çevre eğitiminin eğitim sürecine dahil edilmesinde bir dönüm noktası olarak kabul edilmektedir. Çünkü söz konusu belgelerde çevre eğitiminin ulusal ve uluslararası düzeyde niteliği, hedefleri, amaçları ve pedagojik esasları açıç̧a belirtilmektedir (Ertürk, 1979; Ünal ve Dımışkı, 1999).

Çevre eğitimine ilişkin en somut kararların alındığı 1992 yılında gerçekleştirilen 'Birleşmiş Milletler Çevre ve Kalkınma Konferansı'nda (Rio Dünya Çevre Zirvesi) eğitime sürdürülebilir kalkınma boyutu getirilmiştir. Sürdürülebilir kalkınma bugünkü neslin ihtiyaçları karşılanırken gelecek kuşakların yararlanacağı kaynakların tehlikeye atılmaması amacını taşıyan bir süreç olarak tanımlanmaktadır. Genel olarak ele alındığında 1990'lı yıllarda çevre eğitiminde sürdürülebilirlik için eğitime odaklanılırken 2000'li yıllar itibariyle çevre eğitiminde toplumun işbirliğinin çevre eğitimi üzerindeki etkisine odaklanıldığı görülmektedir (Bildik, 2011; Ünal ve Dımışkı,1999).

Türkiye'de çevre olgusu ilk olarak 1982 Anayasası'ndaki 56. maddede "Herkes sağllkll, dengeli bir çevrede yaşama hakkına sahiptir. Çevreyi geliştirmek, çevre sağlığını korumak ve çevre kirlenmesini önlemek devletin ve vatandaşların görevidir." biçiminde anayasadaki yerini almıştır. $\mathrm{Bu}$ maddenin çevre eğitiminin hedeflerine ulaşmasında önemli yeri olduğu kabul edilmektedir çünkü her bireyin sağlıklı bir çevrede yaşama hakkının sağlanabilmesi için çevre bilincine sahip, sorumlu ve eğitimli nesillerin yetiştirilmesi gerekmektedir. Bu yöndeki ilerlemeler neticesinde ülkemizde çevre eğitimi ancak 1992 yılı itibariyle, eğitim sisteminde ve okulların öğretim programlarında yerini almaya başlamıştır. Bu tarihte ilköğretim Fen Bilgisi Dersi Öğretim Programı'na 'İnsan ve Çevre' konusu dahil edilmiş ayrıca ilkokulların bütün sınıflarında 'Çevre, Sağlık, Trafik, Okuma' dersi verilmeye başlanmıştır. Fakat 'Çevre, Sağlık, Trafik, Okuma' dersi uygulaması 1997 yılı itibariyle kaldırılmıştır (Alkış, 2002; Bulut, 2015). 'Yedinci Beş Yıllık Kalkınma Planı (1996-2000)' Türkiye'de örgün ve yaygın eğitim kapsamında çevre eğitimine ilişkin etkin planlamalar içermektedir. Ardından hazırlanan 'Sekizinci Beş Yıllık Kalkınma Planı (2001-2005)'nda eğitimdeki mevcut eksikliklerin çevre sorunlarının çözümünde aksamalara neden olduğu belirtilirken 'Dokuzuncu Beş Yıllık Kalkınma Planı (2007-2013)'nda sürdürülebilir kalkınmaya değinilmiş, çevre bilincinin arttırılması amacıyla eğitimin ve kamuoyu bilgilendirmelerinin önemi vurgulanmıştır. 'Onuncu Beş Yıllık Kalkınma Planı (2014-2018)'ında ekonomik ve sosyal gelişme sağlanırken toplumdaki çevresel bilinci ve duyarlılığı arttırmanın, bugünün ve gelecek nesillerin sınırlı olan doğal kaynaklardan yararlanmasını güvence altına alarak çevreyi korumanın temel amaç olduğu belirtilmiş̧ir. Son olarak hazırlanan 'On Birinci Beş Yıllık Kalkınma Planı (2019-2023)'nda ise çevrenin ve doğanın korunması için sürdürülebilir üretim ve tüketim konularında eğitim ve bilinçlendirme çalışmalarının gerçekleştirilmesi hedeflenmektedir. 1999'da Çevre Bakanlığı ile Milli Eğitim Bakanlığı arasında imzalanan 'Çevre Eğitimi Konularında Yapılacak Çalışmalara İlişkin İşbirliği Protokolü’ne göre öğrenciler için çevre eğitiminde uygulamalara yer verilmesi, ortaöğretim öğretim programı dahilinde çevre dersinin zorunlu hale gelmesi, öğrencilerin yanı sıra öğretmenlerin de çevre ile ilgili konularda bilinçlendirilmesi amaciyla hizmet içi eğitimler gerçekleştirilmesi gerektiği kabul edilmiştir (Bulut, 2015; Çolakoğlu, 2010; Devlet Planlama Teşkilat1, 1994; Strateji ve Bütçe Başkanlığı, 2014; Strateji ve Bütçe Başkanlığ1, 2019; Yeşilyurt, 2018).

Özellikle son yıllarda ülkemizde Çevre ve Şehircilik Bakanlığı öncülüğünde Milli Eğitim Bakanlığı, Aile ve Sosyal Politikalar Bakanlığı gibi bakanlıklar, çeşitli kamu kuruluşları ve sivil toplum kuruluşlarının işbirliği içine girmesini sağlayacak protokoller yapılarak örgün ve yaygın eğitimde çevre eğitimi uygulanmaktadır. Özellikle örgün öğretimdeki öğretim programlarında, 
çevre eğitimine yönelik bilgilendirme, tutum ve davranış geliştirme amaçlı konular çeşitli derslerin programları içine dağıtılarak verilmeye çalışılmaktadır (Bulut, 2015; Kızıl, 2012).

\section{İlkokul, Ortaokul ve Lise Öğretim Programlarında (Örgün Ĕ̆itimde) Çevre Eğitimi}

Ülkemizde eğitim, örgün ve yaygın şeklinde iki ayrı başlık altında yürütülmektedir. MEB tarafından uygulanmakta olan ilköğretim ve ortaöğretim öğretim programları incelendiğinde ortaokul 7. ve 8. sınıflara yönelik seçmeli ders konumundaki Çevre Eğitimi (2 saat) dersi dışında (ortaokul haftalık ders programında yer almasına rağmen bu seçmeli ders genellikle ögrencilerce seçilmemektedir) çevre eğitimi başlığı altında bir dersin olmadığı görülmektedir. Örgün eğitimde çevre eğitiminden; Hayat Bilgisi, Sosyal Bilgiler, Coğrafya, Fen Bilimleri / Fen ve Teknoloji, Biyoloji, Kimya, Sağlık Bilgisi ve Trafik Kültürü derslerinde ünite bazlı bahsedilmekte, söz konusu derslerin öğretim programlarında çevre ile ilgili kazanımlara yer verilmektedir (Demir ve Yalçın, 2014; Milli Eğitim Bakanlığı, 2018).

\section{1. İlkokul ve Ortaokul Öğretim Programlarında Çevre Ĕgitimi}

İlköğretim (ilkokul ve ortaokul), öğrencilerin temel bilgi ve becerileri kazanarak hayata ve sonraki eğitim kurumlarına hazırlanmasını sağlayan ve bu bağlamda eğitimin temel taş1 sayılabilecek bir dönemdir. Bu dönemde birey ilk defa bir şeyler üretmek ve başarılı olmak için çaba harcamaya başlar, eğer çabaları desteklenirse çalışma ve başarılı olma davranışları, tam tersi tepkilerle karşılaşırsa ise yetersizlik duygusu gelişir. Temel kişilik özelliklerinin de yerleşmeye başladığı bu dönemde alınan eğitimin düzenli ve geliştirmeye açık olması büyük önem taşımaktadır. Bu nedenle; ilköğretim kademesinde çevre eğitimi konusunda da verilmesi gereken bilgi, bilinç ve sorumluluklar diğer eğitim kademelerine göre daha fazla ön plana çıkmaktadır (Erol, 2005; Milli Eğitim Bakanlığı, 2018; Senemoğlu, 1997).

\section{1. İlkokul Hayat Bilgisi Dersinde Çevre Ĕ̆itimi}

2013 yılı Hayat Bilgisi Dersi Öğretim Programı'nda temel çatı 'Birey-Toplum-Doğa' olarak belirlenmiştir. Daha sonra 2018 yılında yeniden güncellenen Hayat Bilgisi Dersi Öğretim Programı'nda ise çevre konusuna ilköğretim 1-2-3. sınıflarında 'Doğada Hayat' ünitesinde değinilmektedir. 2018 yılı öğretim programında yer alan bu ünitede;

-Doğayı tanımak,

-Canlıların hangi yaşam koşullarında yaşayacağını bilmek,

-Çevreyi temiz tutmak gibi temel kazanımlara yer verilmektedir (Milli Eğitim Bakanlığı, 2018; Tay ve Baş, 2015).

1. sınıfa ait Hayat Bilgisi Dersi Öğretim Programı'nda çevre konuları "Doğada Hayat" ünitesinde $\% 16$ oranında yer almaktadır. Bu ünite kapsamında öğrencilere çevresindeki hayvan ve bitkileri tanıma, doğa ve çevre temizliği konularında bilgilenmelerini sağlama ve geri dönüşüme uğrayabilecek ürünleri öğrenme konularında bilgi verilmektedir.

Hayat Bilgisi Dersi 2. sınıf programında çevre konularına "Doğada Hayat" ünitesinde \%18 oranında yer verildiği görülmektedir. Ünite kapsamında öğrencilere bitki yetiştirme, hayvan besleme, iklim, toprak, doğa olayları ve doğal afetler gibi konularda bilgi verilmesi hedeflenmektedir.

3. sınıf Hayat Bilgisi Dersi'nde ise çevre konularına "Doğada Hayat" ünitesinde \%16 oranında yer verilmektedir. Bu ünite sürecinde insanların doğal çevre üzerindeki mevcut etkileri üzerinde durulmakta, atık maddelerin ortamdan toplanma biçimleri ile tekrar kullanıma sunulma alanları örneklendirilmektedir (Tablo 1). 
Tablo 1: İlkokul Hayat Bilgisi Dersi Öğretim Programında Çevre Eğitimi ile ilgili Ünite ve Kazanımlar

\begin{tabular}{|c|c|c|c|c|}
\hline $\begin{array}{c}\text { Sinıf } \\
\text { Düzeyi }\end{array}$ & Ders & Saat & Ünite & Çevre ile İlgili Kazanımlar \\
\hline 1. Sinif & $\begin{array}{l}\text { Hayat } \\
\text { Bilgisi }\end{array}$ & $\begin{array}{c}22 \\
\text { Saat }\end{array}$ & $\begin{array}{c}\text { Doğada } \\
\text { Hayat }\end{array}$ & $\begin{array}{l}\text { - Yakın çevresinde bulunan hayvanları gözlemler } \\
\text { - Yakın çevresinde bulunan bitkileri gözlemler. } \\
\text { - Yakın çevresinde bulunan hayvanları ve bitkileri } \\
\text { korumaya özen gösterir. } \\
\text { - Doğayı ve çevresini temiz tutma konusunda } \\
\text { duyarlı olur. } \\
\text { - Geri dönüşümü yapılabilecek maddeleri ayırt eder. } \\
\text { - Mevsimleri ve özelliklerini araştırır. } \\
\text { - Mevsimlere göre doğada meydana gelen } \\
\text { değişiklikleri kavrar. }\end{array}$ \\
\hline 2. Sinif & $\begin{array}{l}\text { Hayat } \\
\text { Bilgisi }\end{array}$ & $\begin{array}{c}26 \\
\text { Saat }\end{array}$ & $\begin{array}{c}\text { Doğada } \\
\text { Hayat }\end{array}$ & $\begin{array}{l}\text { - Bitki ve hayvanların yaşaması için gerekli olan } \\
\text { şartları karşılaştıır. } \\
\text { - Bitki yetiştirmenin ve hayvan beslemenin önemini } \\
\text { fark eder. } \\
\text { - Yakın çevresindeki doğal unsurların insan } \\
\text { yaşamına etkisine örnekler verir. } \\
\text { - Tüketilen maddelerin geri dönüşümüne katkıda } \\
\text { bulunur. } \\
\text { - Doğa olaylarını tanır. } \\
\text { - Doğal afetlere örnekler verir. } \\
\text { - Doğa olayları ve doğal afetlere karşı alınabilecek } \\
\text { önlemleri açıklar. }\end{array}$ \\
\hline 3. Sinif & $\begin{array}{l}\text { Hayat } \\
\text { Bilgisi }\end{array}$ & $\begin{array}{c}14 \\
\text { Saat }\end{array}$ & $\begin{array}{c}\text { Doğada } \\
\text { Hayat }\end{array}$ & $\begin{array}{l}\text { - İnsan yaşamı açısından bitki ve hayvanların } \\
\text { önemini kavrar. } \\
\text { - Meyve ve sebzelerin yetişme koşullarını araştırır. } \\
\text { - İnsanların doğal unsurlar üzerindeki etkisine yakın } \\
\text { çevresinden örnekler verir. } \\
\text { - Doğa ve çevreyi koruma konusunda sorumluluk } \\
\text { alır. } \\
\text { - Geri dönüşümün kendisine ve yaşadığı çevreye } \\
\text { olan katkısına örnekler verir. }\end{array}$ \\
\hline
\end{tabular}

1.2. İlkokul (4. Sınıf) ve Ortaokul (5., 6. ve 7. Sınıflar) Sosyal Bilgiler Dersinde Çevre Ĕgitimi

İlkokul ve ortaokul Sosyal Bilgiler Dersi Öğretim Programları'nda çevre konularına ait kazanımlara tüm sınıf düzeylerinde genel olarak "İnsanlar, Yerler ve Çevreler' ünitesi içerisinde yer verilmektedir.

4. sınıfa ait Sosyal Bilgiler Dersi Öğretim Programı'nda çevre konularına "İnsanlar, Yerler ve Çevreler' ünitesinde \%18,5 oranında yer değinilmektedir. Ünite kapsamında kazanımlar çevredeki doğal ve beşeri unsurları ayırt etme, doğal afetlere karşı hazırlıklı olma, mevcut kaynaklarla ihtiyaçları ilişkilendirme olarak verilmektedir. Ayrıca tabloya ek olarak "Bilim Teknoloji Toplum" ünitesinde ise;

-Teknolojik ürünlerin çevremizde meydana getirdiği değişikliklerden ve

-Teknolojik ürünlerin doğaya zarar vermeden kullanımının öneminden bahseden kazanımlar bulunmaktadır.

5. sınıf Sosyal Bilgiler Dersi kapsamında çevre konularına "İnsanlar, Yerler ve Çevreler' ünitesi içinde \%16,6 oranında yer verilmiş olup üniteye ait kazanımlar Tablo 2'de belirtilmiştir.

6. sınıf Sosyal Bilgiler Dersi'nde çevre konularına "İnsanlar Yerler ve Çevreler" ünitesinde \%13 oranında yer verildiği görülmektedir. Ayrıca tabloya ek olarak "Üretim Dağıtım Tüketim" 
ünitesinde "Kaynakların bilinçsizce tüketilmesinin canlı yaşamına etkisini analiz eder" kazanımı mevcuttur.

7. sınıf Sosyal Bilgiler Dersi Öğretim Programı'nda ise çevre konularına "İnsanlar, Yerler ve Çevreler" ünitesinde \%13,9 oranında değinilmektedir. Tabloya ek olarak "Üretim, Dağıtım ve Tüketim" ünitesinde "Üretimde ve yönetimde toprağın önemini geçmişten günümüzden örneklerle açıklar" kazanımı yer alırken, "Küresel Bağlantılar" ünitesinde de çevre konusuna değinilmekte ve ünite kapsamında küresel iklim değişikliği, afetler ve göç konuları ele alınarak, öğrencilerin küresel sorunların çözümüne yönelik fikir geliştirmeleri istenmektedir.

Genel olarak Sosyal Bilgiler Dersi Öğretim Programı'nda öğrencilerin yaşadıkları çevreyi tanıyarak, bu çevrede üstlenmeleri gereken rollerden bahsedilmiştir. Bunun yanında programda genel olarak çevre, çevre kirliliği, doğal kaynaklar ve doğal ortam kavramlarına yer verilmiştir (Demir ve Yalçın, 2014). Yine çevrenin önemi, çevre sorunlarının yol açacağı sonuçlar anlatılmış fakat sürdürülebilir bir geleceğe dair konu ve kazanımlar öğretim programında yer almamıştır (Milli Eğitim Bakanlı̆̆ 1 , 2018).

Tablo 2: İlkokul (4. Sınıf) ve Ortaokul (5., 6. ve 7. Sınıflar) Sosyal Bilgiler Dersi Öğretim Programında Çevre Eğitimi ile ilgili Ünite ve Kazanımlar

\begin{tabular}{|c|c|c|c|c|}
\hline $\begin{array}{c}\text { Sinıf } \\
\text { Düzeyi }\end{array}$ & Ders & Saat & Ünite & Çevre ile ilgili Kazanımlar \\
\hline 4. Sinif & $\begin{array}{c}\text { Sosyal } \\
\text { Bilgiler }\end{array}$ & $\begin{array}{c}20 \\
\text { Saat }\end{array}$ & $\begin{array}{l}\text { İnsanlar, } \\
\text { Yerler ve } \\
\text { Çevreler }\end{array}$ & $\begin{array}{l}\text { - Yaşadığı çevredeki doğal ve beşerî unsurları ayırt } \\
\text { eder. } \\
\text { - Çevresinde meydana gelen hava olaylarını } \\
\text { gözlemleyerek bulgularını resimli grafiklere } \\
\text { aktarır. } \\
\text { - Yaşadı̆ı yer ve çevresindeki yer şekilleri ve nüfus } \\
\text { özellikleri hakkında çıarımlarda bulunur. } \\
\text { - Doğal afetlere yönelik gerekli hazırlıkları yapar. }\end{array}$ \\
\hline
\end{tabular}

- Haritalar üzerinde yaşadığı yer ve çevresinin yeryüzü şekillerini genel olarak açıklar.

$\begin{array}{cccc}\text { 5. Sinıf } & \text { Sosyal } & 18 & \text { İnsanlar, } \\ \text { Bilgiler } & \text { Saat } & \text { Yerler ve } \\ \text { Çevreler }\end{array}$
- Yaşadığı çevrede görülen iklimin, insan faaliyetlerine etkisini, günlük yaşantısından örnekler vererek açıklar.

- Yaşadığı yer ve çevresindeki doğal özellikler ile beşerî özelliklerin nüfus ve yerleşme üzerindeki etkilerine örnekler verir.

- Yaşadığı çevredeki afetlerin ve çevre sorunlarının oluşum nedenlerini sorgular.

- Doğal afetlerin toplum hayatı üzerine etkilerini örneklerle açıklar.

- Konum ile ilgili kavramları kullanarak kıtaların, okyanusların ve ülkemizin coğrafi konumunu tanımlar.

- Türkiye'nin temel fiziki coğrafya özelliklerinden yer şekillerini, iklim özelliklerini ve bitki örtüsünü ilgili haritalar üzerinde inceler.

- Türkiye'nin temel beşerî coğrafya özelliklerini ilgili haritalar üzerinde gösterir.

- Dünyanın farklı doğal ortamlarındaki insan yaşantılarından yola çıkarak iklim özellikleri hakkında çıkarımlarda bulunur. 
- Örnek incelemeler yoluyla geçmişten günümüze, yerleşmeyi etkileyen faktörler hakkında çıkarımlarda bulunur.

- Türkiye'de nüfusun dağılışını etkileyen

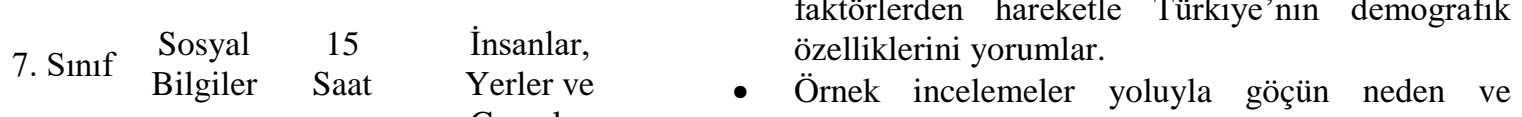
Çevreler sonuçlarını tartışır.

- Temel haklardan yerleşme ve seyahat özgürlüğünün kısıtlanması halinde ortaya çıkacak olumsuz durumlara örnekler gösterir.

\section{3. İlkokul (3. ve 4. Sinıflar) ve Ortaokul (5., 6., 7. ve 8. Sinıflar) Fen Bilimleri Dersinde Çevre Eğitimi}

Bu bölümde ilkokul ve ortaokul kademelerinde öğretim esnasında kullanılmakta olan Fen Bilimleri Dersi Öğretim Programı içerisinde yer alan kazanımlar çevre eğitimi açısından incelenmiștir.

Fen Bilimleri Dersi Öğretim Programı 3. sınıf düzeyinde yer alan çevre eğitimi konularına "Canlılar Dünyasına Yolculuk" ünitesinde \%16,7 oranında yer verilmiş olup öğrencilerin çevrelerindeki örnekleri canlı ve cansız olarak sınıflandırmaları ele alınırken, sistematik kısmı irdelenmemiştir. Ayrıca öğrencilerin doğal çevrelerinin farkına varmaları ve onu korumalarına yönelik kazanımlar da ön plana çıkmaktadır.

Fen Bilimleri Dersi Öğretim Programı 4. sınıf düzeyinde yer alan çevre eğitimi konularına "Aydınlatma ve Ses Teknolojileri" ünitesinde \%9 oranında yer verilmiş olup 1 şık ve ses kirliliğinden bahsedilmiş, öğrencilerin söz konusu kirliliklere yönelik çözüm önerileri üretmeleri istenmiştir. "İnsan ve Çevre" ünitesinde ise \%5,6 oranında çevre konularına değinilmiş, bu ünite kapsamında kaynak kullanımı, geri dönüşüm, tasarruf gibi kavramlar üzerinde durulmuştur.

Fen Bilimleri Dersi Öğretim Programı 5. sınıf düzeyinde yer alan çevre eğitimi konularına "Canlılar Dünyası" ünitesinde \%8,3 oranında, "İnsan ve Çevre" ünitesinde ise \%13,9 oranında yer verilmektedir. Ünitelerde çevrede gerçekleşen kirliliklerden, çevreyi zararlı etkenlerden korumadan, insan ve çevre arasında meydana gelen etkileşim ile yerel ve küresel çevre sorunlarından bahsedilmektedir. Bunların yanında çevre kirliliğinin insan sağlığı üzerindeki etkisinden söz edilmekte, yıkıcı doğa olaylarına ve bunlardan korunma yollarına yer verilmektedir.

Fen Bilimleri Dersi Öğretim Programı 6. sınıf düzeyinde yer alan ve çevre eğitimini kapsayan kazanımlara "Madde ve Isı" ünitesinde yakıtlar bölümünde $\% 4$ oranında yer verilmektedir. Bu ünitede fosil yakıtların tükenebileceği ve yenilenemez enerji kaynakları arasında yer aldığı belirtilirken, rüzgar enerjisi, güneş enerjisi gibi yenilenebilir enerji kaynaklarının canlılık için önemi örnek verilerek vurgulanmaktadır.

Fen Bilimleri Dersi Öğretim Programı 7. sınıf düzeyinde "Saf Madde ve Karışımlar" ünitesi içerisinde $\% 4$ oranında çevre konusuna ait kazanımlara yer verilmektedir. Tablo 3'e ek olarak "Işığın Madde ile Etkileşimi" konusu içerisinde güneş enerjisinin önemine değinilmektedir.

Fen Bilimleri Dersi Öğretim Programı 8. Sınıf düzeyinde yer alan çevre eğitimi konularına "Enerji Dönüşümleri ve Çevre Bilimi" adındaki ünitede \%9,7 oranında yer verilmekte olup madde döngüleri, ozon tabakası, küresel ısınma gibi kavramlar üzerinde durulmaktadır. Ayrıca ünite sürecinde dünya üzerinde yer alan ülkelerin küresel boyutta etkili olan iklim değişikliğinin önüne geçebilmek amacıyla aldıkları önlemlere değinilerek sürdürülebilir kalkınmadan da bahsedilmektedir. Tablo 3.3.'e ek olarak "Mevsimler ve İklim" ünitesi içerisinde küresel iklim değişikliği ve iklim olaylarına yer verilmektedir. "DNA ve Genetik Kod" ünitesi kapsamında biyoteknolojik ürünlerin çevreye etkileri üzerinde durulmakta, "Madde ve Endüstri" ünitesi içerisinde ise asit yağmurlarından ve asit yağmurlarına karşı geliştirilen çözüm önerilerinden bahsedilmektedir. 
Genel olarak bakıldığında Fen Bilimleri Dersi Öğretim Programı'nda, öğrencilerin fen ve teknoloji, çevre ve toplum kavramlarını ilişkilendirmeleri amaçlanmaktadır. Üniteler sonunda öğrencilerin çevrelerindeki canlı ve cansız varlıkları ayırmaları, çevrelerini doğal ve yapay olarak ayırt etmeleri, çevrelerinde meydana gelen olayları gözlemleyip örneklendirebilmeleri, çevre sorunlarına karşı farkındalık kazanıp problemlerin çözümünde kullanabilecekleri bilgi ve becerilere sahip olmaları beklenmektedir (Demir ve Yalçın, 2014; Milli Eğitim Bakanlığı, 2018), (Tablo 3).

Tablo 3: İlkokul (3. ve 4. Sinıflar) ve Ortaokul (5., 6., 7. ve 8. Sinıflar) Fen Bilimleri Dersi Öğretim Programında Yer Alan Çevre Eğitimi Kapsamındaki Ünite ve Kazanımlar

\begin{tabular}{|c|c|c|c|c|}
\hline $\begin{array}{c}\text { Sinıf } \\
\text { Düzeyi }\end{array}$ & Ders & $\begin{array}{l}\text { Ders } \\
\text { Saati }\end{array}$ & Ünite & Çevre ile İlgili Kazanımlar \\
\hline 3. Sinif & $\begin{array}{c}\text { Fen } \\
\text { Bilimleri }\end{array}$ & 18 Saat & $\begin{array}{l}\text { Canlılar } \\
\text { Dünyasına } \\
\text { Yolculuk }\end{array}$ & $\begin{array}{l}\text { - Çevresindeki örnekleri kullanarak varlıkları } \\
\text { canlı ve cansız olarak sınıflandırır. } \\
\text { - } \quad \text { Bir bitkinin yaşam döngüsüne ait gözlem } \\
\text { sonuçlarını sunar. } \\
\text { - } \quad \text { Yaşadığı çevreyi tanır. } \\
\text { - } \quad \text { Yaşadığı çevrenin temizliğinde aktif görev alır. } \\
\text { - Doğal ve yapay çevre arasındaki farkları } \\
\text { açıklar. } \\
\text { - Yapay bir çevre tasarlar. } \\
\text { - Doğal çevrenin canlılar için öneminin farkına } \\
\text { varır. } \\
\text { Doğal çevreyi korumak için araştırma yaparak } \\
\text { çözümler önerir. }\end{array}$ \\
\hline \multirow[t]{2}{*}{ 4.Sinif } & $\begin{array}{c}\text { Fen } \\
\text { Bilimleri }\end{array}$ & 10 Saat & $\begin{array}{l}\text { Aydınlatma } \\
\text { ve Ses } \\
\text { Teknolojileri }\end{array}$ & 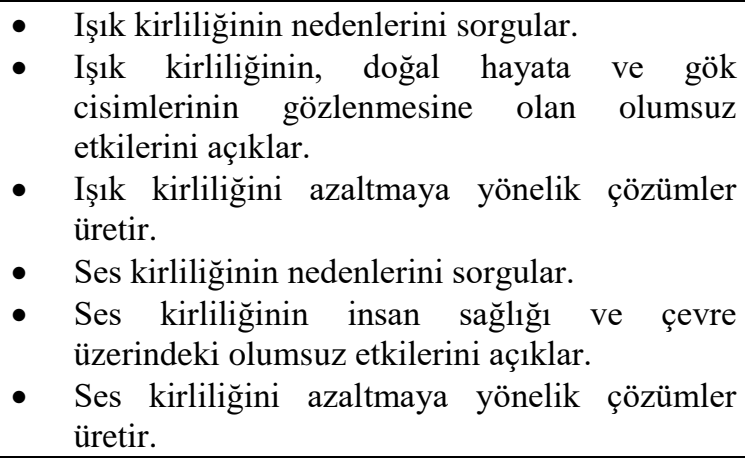 \\
\hline & $\begin{array}{c}\text { Fen } \\
\text { Bilimleri }\end{array}$ & 6 Saat & $\begin{array}{l}\text { İnsan ve } \\
\text { Çevre }\end{array}$ & $\begin{array}{l}\text { - Kaynakların kullanımında tasarruflu } \\
\text { davranmaya özen gösterir } \\
\text { - Yaşam için gerekli olan kaynakların ve geri } \\
\text { dönüşümün önemini fark eder. }\end{array}$ \\
\hline 5. Sinif & $\begin{array}{c}\text { Fen } \\
\text { Bilimleri }\end{array}$ & 12 Saat & $\begin{array}{l}\text { Canlılar } \\
\text { Dünyası }\end{array}$ & $\begin{array}{l}\text { - Canlılara örnekler vererek benzerlik ve } \\
\text { farklılıklarına göre sinıflandırır. }\end{array}$ \\
\hline
\end{tabular}


- Biyoçeşitliliğin doğal yaşam için önemini sorgular.

- Biyoçeşitliliği tehdit eden faktörleri, araştırma verilerine dayalı olarak tartışır.

- İnsan ve çevre arasındaki etkileşimin önemini ifade eder.

$\begin{array}{ccc}\text { Fen } & \text { İnsan ve } \\ \text { 5. Sınıf } & \text { Bilimleri } & \text { 20 Saat }\end{array}$

6. Sinif Fen 6 Saat Madde ve Is1 Bilimleri

\begin{tabular}{cccc} 
6. Sınıf & $\begin{array}{c}\text { Fen } \\
\text { Bilimleri }\end{array}$ & 6 Saat & Madde ve Isı \\
\hline 7. Sınıf & $\begin{array}{c}\text { Fen } \\
\text { Bilimleri }\end{array}$ & 6 Saat & $\begin{array}{c}\text { Saf Madde } \\
\text { ve Karısıımlar }\end{array}$
\end{tabular}

- Yakın çevresindeki veya ülkemizdeki bir çevre sorununun çözümüne iliş̧in öneriler sunar.

- İnsan faaliyetleri sonucunda gelecekte oluşabilecek çevre sorunlarına yönelik çıkarımda bulunur.

- İnsan-çevre etkileşiminde yarar ve zarar durumlarını örnekler üzerinde tartı̧ıır.

- Doğal süreçlerin neden olduğu yıkıcı doğa olaylarını açıklar.

- Yıkıcı doğa olaylarından korunma yollarını ifade eder.

- Yakıtları, katı, sivı ve gaz yakitlar olarak sınıflandırıp yaygın şekilde kullanılan yakıtlara örnekler verir.

- Farklı türdeki yakıtların 1Sı amaçlı kullanımının, insan ve çevre üzerine etkilerini tartışır.

- Soba ve doğal gaz zehirlenmeleri ile ilgili alınması gereken tedbirleri araştırır ve rapor eder.

- Evsel atıklarda geri dönüştürülebilen ve dönüştürülemeyen maddeleri ayırt eder.

- Evsel katı ve sıvı atıkların geri dönüşümüne ilişkin proje tasarlar.

- Geri dönüşümü, kaynakların etkili kullanımı açısından sorgular.

- Yakın çevresinde atık kontrolüne özen gösterir.

- Yeniden kullanılabilecek eşyalarını, ihtiyacı olanlara iletmeye yönelik proje geliştirir.

- Madde döngülerini şema üzerinde göstererek açıklar.

- Madde döngülerinin yaşam açısından önemini sorgular.

- Küresel iklim değişikliklerinin nedenlerini ve olası sonuçlarını tartışır.

- Kaynakların kullanımında tasarruflu davranmaya özen gösterir.

- Kaynakların tasarruflu kullanımına yönelik proje tasarlar.

- Geri dönüşüm için katı atıkların ayrıştırılmasının önemini açıklar.

- Geri dönüşümün ülke ekonomisine katkısına ilişkin araştırma verilerini kullanarak çözüm önerileri sunar.

- Kaynakların tasarruflu kullanılmaması durumunda gelecekte karşılaşılabilecek problemleri belirterek çözüm önerileri sunar. 


\section{Incelenmesi \\ 1.4. Ortaokul (7. ve 8. Sınıflar) Seçmeli 'Çevre Eğitimi’ Dersi Öğretim Programının}

Zaman içinde doğal dengede meydana gelen bozulma çevre sorunlarını gündeme getirmiştir. Tür çeşitliliğinin azalması, ormansızlaşma, incelen ozon tabakası, su kirliliği, değişen iklim koşulları doğanın dengesini bozmakta ve çevre sorunlarını oluşturmaktadır. Son yıllarda doğal dengenin korunması için sürdürülebilir kalkınma anlayışı büyük önem kazanmıştır. Ülkemizde çevre eğitimi, temel derslerin içine yedirilmiş olarak uygulanmakta olup ayrı bir Çevre Eğitimi dersi olarak okutulmamaktadır. Çevre sorunlarının giderek artmasından dolayı ayrı bir çevre eğitimi dersinin gerekli olduğu düşünülmeye başlanmış ve 2015 yılında Ortaöğretim Öğretim Programı için seçmeli Çevre Eğitimi dersi önerilmiştir (Milli Eğitim Bakanlığı, 2015). Ancak ortaokullarda Çevre Eğitimi dersinin çok az ögrenci tarafindan seçildiği bilinen bir gerçektir. 2015 yılında Ortaöğretim Öğretim Programı için hazırlanan seçmeli Çevre Eğitimi dersi için önerilen ders saati Tablo 4'de belirtilmiştir.

Ders içeriği incelendiğinde; "Doğanın Dengesi" ünitesine \%13,89 oranında yer verildiği görülmektedir. $\mathrm{Bu}$ ünitede çevre kavramı, insanların yaptığı hataların çevre üzerinde etkileri, teknolojinin düzgün kullanılmamasının yarattığı çevre sorunları gibi konulara değinilmektedir. "Madde Döngüsü ve Doğal Denge" ünitesine \%22,22 oranında yer verilmiş olup bu ünitede ayrıntıya girilmeden madde döngüleri anlatılmaktadır. Madde döngüleri üzerinde insan etkileri olduğunda çevresel sorunların ortaya çıkacağından bahsedilmektedir. "Kaynakların Sınırlılığı ve Ekolojik Ayak İzi" ünitesine \%16,67 oranında yer verilmiş, bu ünitede küresel 1sınmadan, ekolojik ayak izinden, tehlikeli atıkların doğaya zarar verilmeden nasıl yok edilmesi gerektiğinden söz edilmektedir. Öğrencilere yenilenebilir enerji kaynaklarının sınırlı olduğu, doğal kaynakların da tükenebileceği bilgisi verilmek istenmektedir. "Küresel Çevre Sorunları" ünitesine ise \%30,56 oranında yer verilmiştir. Bu ünitede Kyoto Protokolü ve diğer küresel ölçekte çevre sorunlarının konuşulduğu konferanslardan ve Türkiye'nin bu faaliyetlerdeki rolünden bahsedilmektedir. Son olarak "Çevre Dostu Çözümler ve Stratejiler" ünitesine \%16,67 oranında yer verilerek, ünitede ağırlıklı olarak geri dönüşümden söz edilmektedir.

Tablo 4: Ortaöğretim Seçmeli ‘Çevre Eğitimi’ Dersi Öğretim Programı Ünite ve Kazanımları

\begin{tabular}{|c|c|c|c|c|}
\hline $\begin{array}{c}\text { Sinıf } \\
\text { Düzeyi }\end{array}$ & Ders & Ders Saati & Ünite & Kazanımlar \\
\hline $\begin{array}{l}\text { 7. ve } 8 . \\
\text { Sinif }\end{array}$ & $\begin{array}{l}\text { Çevre } \\
\text { Eğitimi }\end{array}$ & 10 Saat & $\begin{array}{l}\text { Doğanın } \\
\text { Dengesi }\end{array}$ & $\begin{array}{l}\text { - Doğadaki tüm canlı ve cansız varlıkların } \\
\text { birbiriyle etkileşim halinde olduğunu kavrar. } \\
\text { - Doğa denge kavramını ve dünyanın hassas bir } \\
\text { doğal dengeye sahip olduğunu açıklar. } \\
\text { - İnsan faaliyetlerinin doğal dengeyi nasıl } \\
\text { etkilediği konusunda çıkarımda bulunur. } \\
\text { - Yaşadığı çevrede insan faaliyetlerinin doğal } \\
\text { dengeyi nasıl etkilediğini, çevreye ne tür } \\
\text { zararlar verdiğini gözlemler ve gözlemlerini } \\
\text { ifade eder. } \\
\text { - İnsan faaliyetlerinin doğal dengeyi nasıl } \\
\text { etkilediğini yaşadıkları çevreden, ülkeden } \\
\text { dünyadan örneklerle açılar. } \\
\text { Doğal dengenin korunması için insan } \\
\text { faaliyetlerinin nasıl düzenlenebileceği veya } \\
\text { değiştirilebileceği konusunda fikir ve öneriler } \\
\text { geliştirir. }\end{array}$ \\
\hline
\end{tabular}

Turkish Studies, 15(5) 


\begin{tabular}{|c|c|c|c|c|}
\hline $\begin{array}{c}\text { 7. ve } 8 . \\
\text { Sinıf }\end{array}$ & $\begin{array}{c}\text { Çevre } \\
\text { Eğitimi }\end{array}$ & 16 Saat & $\begin{array}{c}\text { Madde } \\
\text { Döngüsü ve } \\
\text { Doğal } \\
\text { Denge }\end{array}$ & 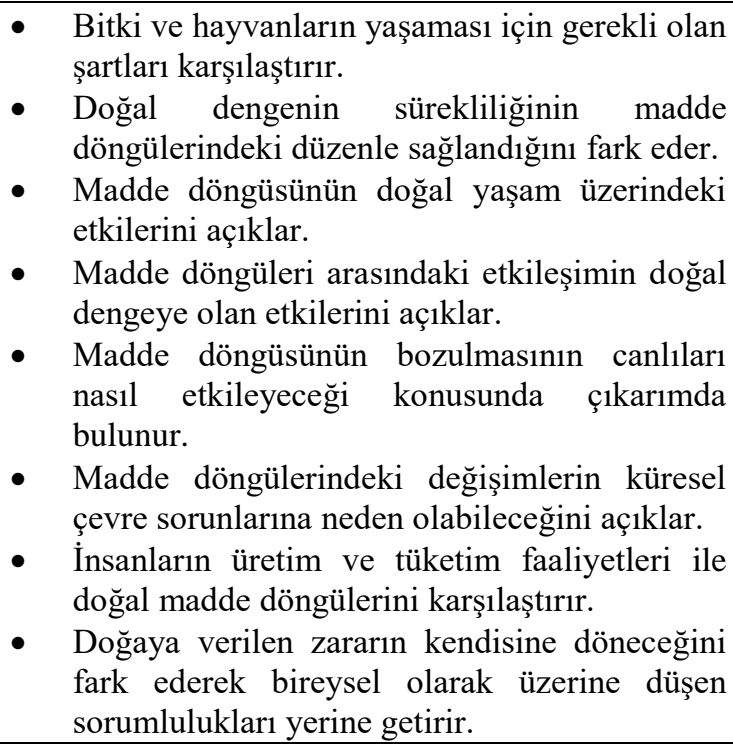 \\
\hline $\begin{array}{c}\text { 7. ve } 8 . \\
\text { Sinıf }\end{array}$ & $\begin{array}{c}\text { Çevre } \\
\text { Eğitimi }\end{array}$ & 12 Saat & $\begin{array}{c}\text { Kaynakların } \\
\text { Sinırlılığı } \\
\text { ve Ekolojik } \\
\text { Ayak İzi }\end{array}$ & $\begin{array}{l}\text { - Nüfusun üretim ve tüketim faaliyetlerinin } \\
\text { çevre sorunlarının ortaya çımasına etkisini } \\
\text { açıklar. } \\
\text { - } \\
\text { - } \text { Kenolojik ayak izini açıklar. } \\
\text { kaynak tüketimine etkisini yorumlar. } \\
\text { - Doğal kaynak tüketiminin dünyanın insan } \\
\text { yaşamını destekleme kapasitesini azaltmadan } \\
\text { nasıl yapılabileceğini tartışır. } \\
\text { - Sürdürülebilir doğal kaynak kullanımının } \\
\text { sürdürülebilir kalkınmaya katkısını irdeler. } \\
\text { Dünyadaki kaynakların sınırlı olduğunu } \\
\text { bilerek kaynakları tasarruflu kullanır. } \\
\text { Çevre dostu tüketim maddelerini kullanmaya } \\
\text { özen gösterir. }\end{array}$ \\
\hline $\begin{array}{c}\text { 7. ve } 8 . \\
\text { Sinıf }\end{array}$ & $\begin{array}{l}\text { Çevre } \\
\text { Eğitimi }\end{array}$ & 22 Saat & $\begin{array}{l}\text { Küresel } \\
\text { Çevre } \\
\text { Sorunları }\end{array}$ & $\begin{array}{l}\text { - Ormansızlaşma, küresel 1sınma, iklim } \\
\text { değişikliği ve biyolojik çeşitliliğin azalmasını } \\
\text { temel küresel çevre problemleri olarak } \\
\text { tanımlar. } \\
\text { Ozon tabakasının incelmesi, asit yağmurları, } \\
\text { küresel ısınma, ormansızlaşma vb. çevre } \\
\text { sorunlarının ortaya çıkış nedenlerini inceler. } \\
\text { - Ormansızlaşma, iklim değişikliği ve biyolojik } \\
\text { çeşitliliğin azalması arasında ki ilişkiyi açıklar. } \\
\text { Hava, su, toprak, gürültü ve ışı kirliliğinin } \\
\text { yerel ve küresel ölçekte ortaya çıkardığı } \\
\text { sorunları irdeler. } \\
\text { Hava, su, toprak, gürültü ve ışık kirliliğinin } \\
\text { önlenmesinde kendine düşen sorumlulukları } \\
\text { yerine getirir. } \\
\text { Su kaynaklarının azalmasının } \\
\text { kirletilmesinin canlılar üzerindeki etkilerini } \\
\text { açıklar. } \\
\text { İklim değişikliğinin dünyadaki yaşamı nasıl } \\
\text { etkileyeceği hakkında kestirimler yapar } \\
\text { Biyolojik çeşitliliğin azalmasının doğal } \\
\text { dengeyi nasıl etkileyeceğini açıklar. }\end{array}$ \\
\hline
\end{tabular}




\begin{tabular}{|c|c|c|c|c|}
\hline & & & & $\begin{array}{l}\text { - } \begin{array}{l}\text { Ormansızlaşmanın doğal dengeyi nasıl } \\
\text { etkileyeceğini açıklar. }\end{array} \\
\text { - } \quad \text { Çölleşmenin doğal yaşam üzerindeki etkilerini } \\
\text { açıklar. } \\
\text { - Ozon tabakasının incelmesinin canlıların } \\
\text { sağlığı üzerindeki etkilerini değerlendirir. } \\
\text { Küresel açlığı engellemek için bireysel olarak } \\
\text { kendisine düşen sorumlulukları yerine getirir. }\end{array}$ \\
\hline $\begin{array}{c}\text { 7. ve } 8 . \\
\text { Sinif }\end{array}$ & $\begin{array}{l}\text { Çevre } \\
\text { Eğitimi }\end{array}$ & 12 Saat & $\begin{array}{c}\text { Çevre } \\
\text { Dostu } \\
\text { Çözümler } \\
\text { ve } \\
\text { Stratejiler }\end{array}$ & 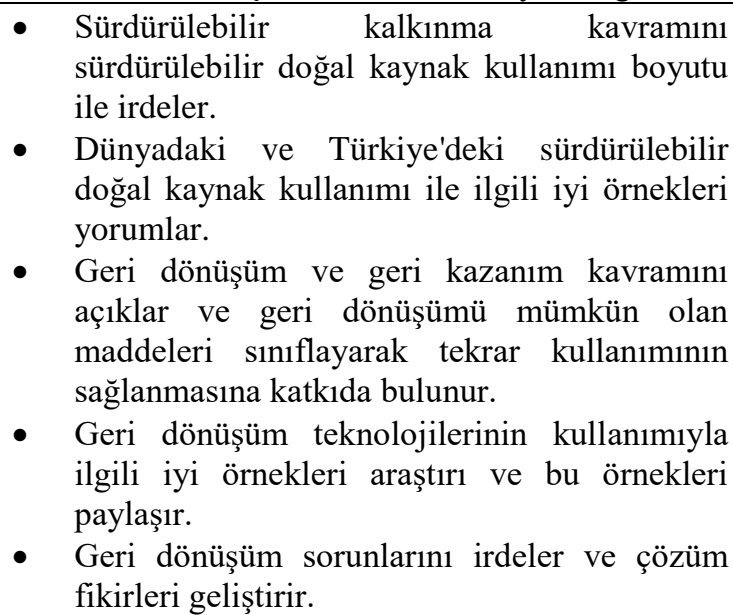 \\
\hline
\end{tabular}

\subsection{Ortaokul (5., 6., 7. ve 8. Sınıflar) Seçmeli 'Şehrimiz...’ Dersi Öğretim Programının}

\section{Incelenmesi}

'Şehrimiz ...' Dersi Öğretim Programı 5., 6., 7. ve 8. sınıf düzeylerinde seçilmek üzere, haftada iki ders saati olarak toplam 72 saatlik bir süre öngörülerek hazırlanmıştır.

'Şehrimiz...' Dersi Öğretim Programı'nda çevre eğitimine "Şehrimi Tanıyorum" ünitesi kapsamında \%11 oranında yer verilmektedir. Ünite kapsamında öğrencinin yaşadığ şehrin fiziki ve coğrafi özellikleri, doğal afetler ve meydana gelen doğal afetlere karşı alınması gereken önlemlerden bahsedilmektedir (Milli Eğitim Bakanlı̆̆ı, 2017). (Tablo 5).

Tablo 5: Ortaöğretim Seçmeli ‘Şehrimiz...' Dersi Öğretim Programı Ünite ve Kazanımları

\begin{tabular}{|c|c|c|c|c|}
\hline $\begin{array}{c}\text { Sinıf } \\
\text { Düzeyi }\end{array}$ & Ders & Ders Saati & Ünite & Kazanımlar \\
\hline $\begin{array}{l}\text { 5.,6., } \\
7 ., 8 . \\
\text { Sinif }\end{array}$ & Şehrimiz... & 9 Saat & $\begin{array}{c}\text { Şehrimi } \\
\text { Tanıyorum }\end{array}$ & $\begin{array}{l}\text { - Yaşadığ } \text { ilin coğrafi konumunu ve } \\
\text { coğrafi özelliklerini araştırır. } \\
\text { - Yaşadığ } 1 \text { şehirdeki insan doğa } \\
\text { etkileşimini açiklar. } \\
\text { - Yaşadığı şehirde karşılaşılabilecek doğal } \\
\text { afetleri araştırır. }\end{array}$ \\
\hline
\end{tabular}

\section{Ortaöğretim Öğretim Programlarında Çevre Ĕ̆itimi}

Ortaöğretim dönemindeki öğrenciler öğrenmeye istekli, aktif katılıma müsait, önceki öğrenmelerini davranışlarına yansıtabilen ve çevre eğitimi temelini almış bir düzeye ulaşmışlardır. Çevre eğitimi hakkında gerçekleştirilen çalışmalar, bireylerin çevre eğitiminden en yüksek verimi alabilecekleri öğretim seviyesinin ortaöğretim olduğunu göstermektedir (Ünal ve Dımışk1, 1999). Fakat bu derece önemli bir dönem olmasına karşın ülkemizde ortaöğretim programlarında çevre eğitimi adı altında ayrı bir ders bulunmamakta ve çevre eğitimi zorunlu derslerden Biyoloji, Kimya, Coğrafya gibi ders programlarına entegre edilmiş olarak verilmektedir (Bulut, 2015; Erdoğan, Bahar ve Uşak, 2012; Milli Eğitim Bakanlığı, 2018). 


\subsection{Ortä̈ğretim Coğrafya Dersinde Çevre Eğitimi}

Ortaöğretim kademesinde yer alan Coğrafya Dersi Öğretim Programı sınıf düzeyleri dikkate alınarak incelendiğinde; 9. sınıfa ait ders programında çevre konularına \%7 oranında "Çevre ve Toplum" ünitesinde, 10. sınıf ders programında çevre konularına \%11 oranında "Çevre ve Toplum" ünitesinde, 11. sınıf Coğrafya Dersi Öğretim Programı'nda ise çevre konularına \%11 oranında "Çevre ve Toplum" ünitesinde, \%8 oranında "Doğal Sistemler" ünitesinde ve \%11 oranında "Beşerî Sistemler" ünitesi içerisinde yer verildiği görülmektedir. Ayrıca "Doğal Sistemler" ünitesinde de çevreye ait biyoçeşitlilik, ekosistem gibi konulardan bahsedilmiştir. 12. sınıf Coğrafya Dersi Öğretim Programı'nda çevre konularına \%8 oranında "Çevre ve Toplum" ünitesinde, $\% 8$ oranında da "Doğal Sistemler" ünitesinde yer verilmiştir.

Genel olarak bakıldığında Ortaöğretim Coğrafya dersinde çevre konularına oran olarak az ağırlık verilmiş olsa da öğrencilerin doğal afetler ve çevre sorunları üzerinde durularak bunlara yönelik önlem alma ve korunma amaçlı uygulamalar geliştirebilmesi, doğaya karşı duyarlılık kazanmaları, toprakların verimli kullanılması gerekliliği ve gelecek nesillerce yaşanabilir bir dünya kavramları üzerinde durulmuştur. Bunlar yanında endemizmin önemi ve doğanın korunması ve ona sahip çıkılması gerektiği örneklerle açıklanmıştır (Milli Eğitim Bakanlığı, 2018). (Tablo 6).

Tablo 6: Ortaöğretim Coğrafya Dersi Öğretim Programında Yer Alan Çevre Eğitimi Kapsamındaki Ünite ve Kazanımlar

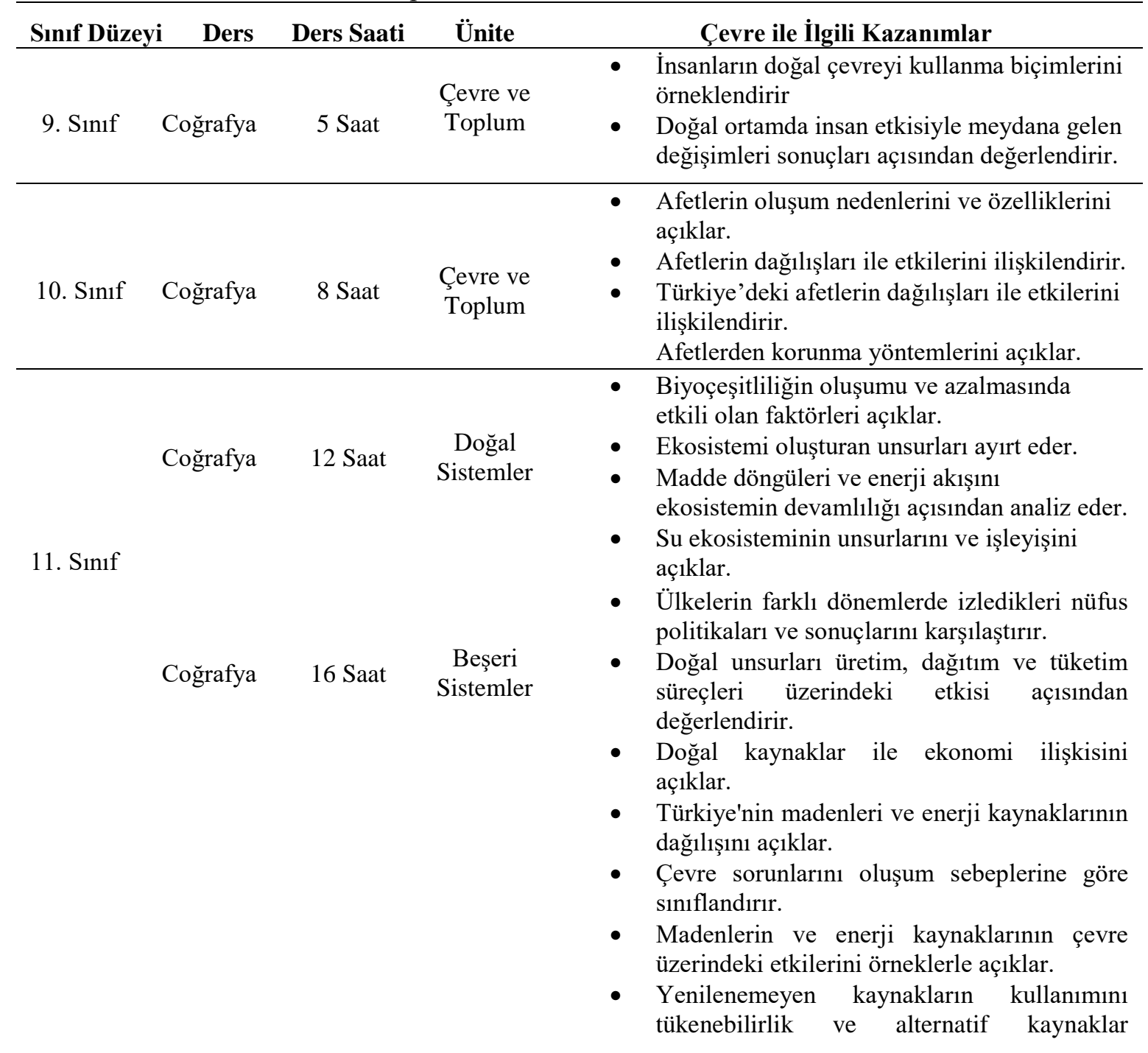




\begin{tabular}{|c|c|c|c|c|}
\hline & Coğrafya & 16 saat & $\begin{array}{l}\text { Çevre ve } \\
\text { Toplum }\end{array}$ & $\begin{array}{l}\text { açısından analiz eder. } \\
\text { - Farklı gelişmişliğe sahip ülkelerdeki doğal } \\
\text { kaynak kullanımını çevresel etkileri açısından } \\
\text { değerlendirir. } \\
\text { - Arazi kullanımına ilişkin farklı uygulamaları } \\
\text { çevre üzerindeki etkileri açısından } \\
\text { değerlendirir. } \\
\text { - Çevre sorunlarının oluşum ve yayılma } \\
\text { süreçlerini küresel etkileri açısından analiz } \\
\text { eder. } \\
\text { Doğal kaynakların sürdürülebilir kullanımını } \\
\text { geri dönüşüm stratejileri açısından } \\
\text { değerlendirir. }\end{array}$ \\
\hline 12.Sinif & Coğrafya & 12 saat & $\begin{array}{c}\text { Doğal } \\
\text { Sistemler }\end{array}$ & 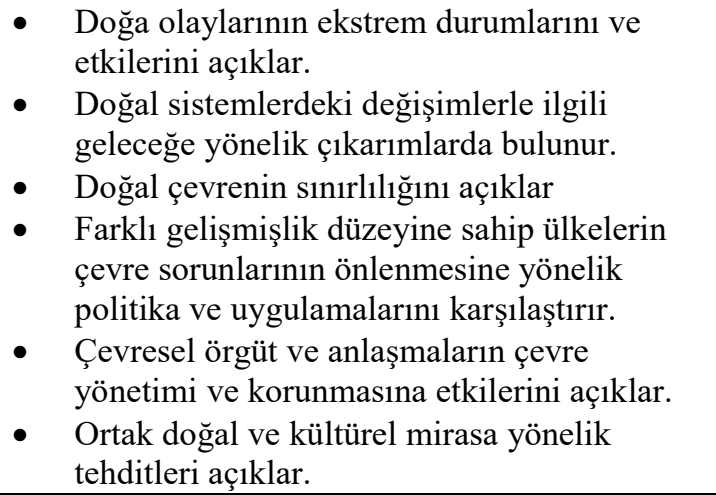 \\
\hline
\end{tabular}

\subsection{Ortaöğretim Biyoloji Dersi Öğretim Programında Çevre Ĕ̆itimi}

Biyoloji Dersi Öğretim Programı 9. Sınıf düzeyinde çevre eğitimine "Canlılar Dünyası" ünitesi kapsamında \%33,3 oranında, 10. sınıf öğretim programında "Ekosistem Ekolojisi ve Güncel Çevre Sorunları" ünitesinde \%33,3 oranında, 11. sınıf öğretim programında "Komünite ve Popülasyon Ekolojisi" ünitesinde \%19,4 oranında ve 12. sınıf öğretim programında ise "Canlılar ve Çevre" ünitesinde \%8,3 oranında yer verilmektedir.

Genel olarak Biyoloji Dersi Öğretim Programı'nın temeli güncel çevre sorunlarına yer vermek ve bunlar ile ilgili çözüm önerileri sunmaktır. Programda, öğrencilerin çevre bilinci edinmeleri, çevre üzerine olumsuz etkilerinin farkında olmaları, bu sorunlara yönelik çözüm önerileri geliştirebilmeleri ve çevre sorunlarının insanlara olan etkilerini kavramları amaçlanmaktadır (Milli Eğitim Bakanlığı, 2018). (Tablo 7).

Tablo 7: Ortaöğretim Biyoloji Dersi Öğretim Programında Yer Alan Çevre Eğitimi

Kapsamındaki Ünite ve Kazanımlar

\begin{tabular}{|c|c|c|c|c|}
\hline $\begin{array}{c}\text { Sinıf } \\
\text { Düzeyi }\end{array}$ & Ünite Adı & $\begin{array}{l}\text { Ders } \\
\text { Saati }\end{array}$ & $\begin{array}{c}\text { Kazanım } \\
\text { Sayısı } \\
\end{array}$ & Çevre ile İlgili Kazanımlar \\
\hline 9. Sinif & $\begin{array}{l}\text { Canlılar } \\
\text { Dünyası }\end{array}$ & $\begin{array}{c}24 \\
\text { Saat }\end{array}$ & $\begin{array}{c}5 \\
\text { Kazanım }\end{array}$ & $\begin{array}{l}\text { - } \quad \text { Canlıların çeşitliliğinin anlaşılmasında } \\
\text { sinıflandırmanın önemini açıllar. } \\
\text { - } \quad \text { Canlıların sınıflandırılmasında kullanılan } \\
\text { kategorileri ve bu kategoriler arasındaki } \\
\text { hiyerarşiyi örneklerle açıklar. } \\
\text { - } \quad \text { Canlıların sınıflandırılmasında kullanılan âlemleri } \\
\text { ve bu âlemlerin genel özelliklerini açıklar. } \\
\text { - Canlıların biyolojik süreçlere, ekonomiye ve } \\
\text { teknolojiye katkılarını örneklerle açıklar. } \\
\text { - Virüslerin genel özelliklerini açıklar. }\end{array}$ \\
\hline & & & & - $\quad$ Ekosistemin canlı ve cansız bileşenleri arasındaki \\
\hline
\end{tabular}




\begin{tabular}{|c|c|c|c|c|}
\hline 10. Sinif & $\begin{array}{l}\text { Ekosistem } \\
\text { Ekolojisi } \\
\text { ve Güncel } \\
\text { Çevre } \\
\text { Sorunlar1 }\end{array}$ & $\begin{array}{c}24 \\
\text { Saat }\end{array}$ & $\begin{array}{c}10 \\
\text { Kazanım }\end{array}$ & $\begin{array}{l}\text { ilişkiyi açıklar. } \\
\text { - Canlılardaki beslenme şekillerini örneklerle } \\
\text { açıklar. } \\
\text { - } \quad \text { Ekosistemde madde ve enerji akışını analiz eder. } \\
\text { - Madde döngüleri ve hayatın sürdürülebilirliği } \\
\text { arasında ilişki kurar. } \\
\text { - } \quad \begin{array}{l}\text { Güncel çevre sorunlarının sebeplerini ve olası } \\
\text { sonuçlarını değerlendirir. } \\
\text { - Birey olarak çevre sorunlarının ortaya } \\
\text { çıkmasındaki rolünü sorgular. } \\
\text { - Yerel ve küresel bağlamda çevre kirliliğinin } \\
\text { önlenmesine yönelik çözüm önerilerinde bulunur. } \\
\text { - Doğal kaynakların sürdürülebilirliğinin önemini } \\
\text { açıklar. } \\
\text { - Biyolojik çeşitliliğin yaşam için önemini sorgular. } \\
\text { - Biyolojik çeşitliliğin korunmasına yönelik çözüm } \\
\text { önerilerinde bulunur. }\end{array} \\
\end{array}$ \\
\hline 11. Sinıf & $\begin{array}{l}\text { Komünite } \\
\text { ve } \\
\text { Popülasyon } \\
\text { Ekolojisi }\end{array}$ & $\begin{array}{l}28 \\
\text { Saat }\end{array}$ & $\begin{array}{c}5 \\
\text { Kazanım }\end{array}$ & $\begin{array}{ll}\text { - } & \text { Komünitenin yapısına etki eden faktörleri açıklar. } \\
\text { - } & \text { Komünitede tür içi ve türler arasındaki rekabeti } \\
& \text { örneklerle açıklar. } \\
\text { - } & \text { Komünitede türler arasında simbiyotik ilişkileri } \\
& \text { örneklerle açıklar. } \\
\text { - } & \text { Komünitelerdekisüksesyonu örneklerle açıklar. } \\
\text { - } & \text { Popülasyon dinamiğine etki eden faktörleri analiz } \\
& \text { eder. }\end{array}$ \\
\hline 12. Sinif & $\begin{array}{l}\text { Canlılar ve } \\
\text { Çevre }\end{array}$ & $\begin{array}{c}12 \\
\text { Saat }\end{array}$ & $\begin{array}{c}2 \\
\text { Kazanım }\end{array}$ & $\begin{array}{l}\text { - Çevre şartlarının genetik değişimlerin } \\
\text { sürekliliğine olan etkisini açılar. } \\
\text { - Tarım ve hayvancılıkta yapay seçilim } \\
\text { uygulamalarına örnekler verir. }\end{array}$ \\
\hline
\end{tabular}

\section{Ĕgitimi}

2.3. Ortä̈̆̆retim 'Sağlık Bilgisi ve Trafik Kültürü' Dersi Öğretim Programında Çevre

Ortaöğretim Öğretim Programları incelendiğinde 9. Sınıf düzeyinde temel derslere ek olarak "Sağlık Bilgisi ve Trafik Kültürü" dersinde de çevre konularına yer verildiği görülmektedir. "Sağlık Bilgisi ve Trafik Kültürü" dersi kapsamında öğrencilere gürültü kirliği, radyasyon kirliliği, hava ve su kirliliğii, kanserojen maddeler, Genetiği Değiş̧irilmiş Organizmalar (GDO) gibi konular hakkında bilgi verilmekte ayrıca çevresel etmenlerin insan ve toplum sağlığı üzerindeki olumsuz etkileri anlatılmaktadır.

Dersin trafik ile ilgili içeriğine bakıldığında ise trafikten kaynaklanan çevre kirliliğinin günümüzde ulaştı̆̆ boyutlara değinilerek, bisiklet kullanmanın, toplu taşıma ile seyahat etmenin çevre kirliliğinin önlenmesine ve ülke ekonomisine sağlayacağı katkılardan bahsedilmektedir.

\subsection{Ortaöğretim Kimya Dersi Öğretim Programında Çevre Ĕ̆itimi}

Kimya Dersi Öğretim Programı 9. sınıf düzeyinde çevre eğitimine "Doğa ve Kimya" ünitesi kapsamında \%11 oranında yer verilmiştir. 10. sınıf Kimya Dersi Öğretim Programı’nda ise "Asitler, Bazlar ve Tuzlar" ünitesinde 2 kazanımda ve "Kimya Her Yerde" ünitesinde 3 kazanımda $\%$ 13,9 oranında çevre konularına yer verilmektedir. Ayrıca 12. sınıf Kimya Dersi Öğretim Programı'nda çevre eğitimine "Enerji Kaynakları ve Bilimsel Gelişmeler" ünitesinde \%18 oranında yer verilmektedir.

Genel olarak bakıldığında programda su kaynaklarının önemi vurgulanmış, tüketim maddelerinin doğa ile uyumlu olması gerektiği, bilinçsizce tüketilen fosil yakıtların zararı, atık maddelerin doğayı kirletmesi gibi konulara değinilmiştir. Kimya Dersi Öğretim Programı’nda 
ayrıca çevre temizliği farkındalığı ve sürdürülebilir gelecek konularına da yer verilmiştir (Milli Eğitim Bakanlığı, 2018). (Tablo 8).

Tablo 8: Ortaöğretim Kimya Dersi Öğretim Programında Yer Alan Çevre Eğitimi Kapsamındaki Ünite ve Kazanımlar

\begin{tabular}{|c|c|c|c|c|}
\hline $\begin{array}{c}\text { Sinıf } \\
\text { Düzeyi }\end{array}$ & Ünite Adı & $\begin{array}{l}\text { Ders } \\
\text { Saati }\end{array}$ & $\begin{array}{c}\text { Kazanım } \\
\text { Sayısı }\end{array}$ & Çevre ile İlgili Kazanımlar \\
\hline 9. Sinif & $\begin{array}{l}\text { Doğa ve } \\
\text { Kimya }\end{array}$ & $\begin{array}{c}8 \\
\text { Saat }\end{array}$ & $\begin{array}{c}5 \\
\text { Kazanım }\end{array}$ & $\begin{array}{l}\text { - Suyun varlıklar için önemini açıklar. } \\
\text { - Su tasarrufuna ve su kaynaklarının korunmasına } \\
\text { - yönelik çözüm önerileri geliştirir. } \\
\text { Hava, su ve toprak kirliliğine sebep olan } \\
\text { kimyasal kirleticileri açıklar. } \\
\text { - Suyun sertlik ve yumuşaklık özelliklerini } \\
\text { açklar. } \\
\text { CCevreye zarar veren kimyasal kirleticilerin } \\
\text { etkilerinin azaltılmas konusunda çözüm } \\
\text { önerilerinde bulunur. }\end{array}$ \\
\hline & $\begin{array}{l}\text { Asit Bazlar } \\
\text { ve Tuzlar }\end{array}$ & $\begin{array}{c}4 \\
\text { Saat }\end{array}$ & 2 Kazanım & $\begin{array}{l}\text { - Asitlerin ve bazların fayda ve zararlarını açıklar. } \\
\text { - Asit ve bazlarla çalışırken alınması gereken } \\
\text { sağlık ve güvenlik önlemlerini açıklar. } \\
\end{array}$ \\
\hline 10. Sinıf & $\begin{array}{c}\text { Kimya Her } \\
\text { Yerde }\end{array}$ & $\begin{array}{c}6 \\
\text { Saat }\end{array}$ & $\begin{array}{c}3 \\
\text { Kazanım }\end{array}$ & $\begin{array}{l}\text { - Polimer, kağıt, cam ve metal malzemelerin geri } \\
\text { dönüşümünün ülke ekonomisine katkısını } \\
\text { açıklar. } \\
\text { Kozmetik malzemelerin içerebileceği zararlı } \\
\text { kimyasalları açıklar. } \\
\text { - İlaçları farklı formlarda kullanılmasının } \\
\text { nedenlerini açıklar. }\end{array}$ \\
\hline 12. Sinif & $\begin{array}{c}\text { Enerji } \\
\text { Kaynakları } \\
\text { ve Bilimsel } \\
\text { Gelişmeler }\end{array}$ & $\begin{array}{c}26 \\
\text { Saat }\end{array}$ & 5 Kazanım & $\begin{array}{l}\text { - Fosil yakıtların çevreye zararlı etkilerini } \\
\text { azaltmak için çözüm önerilerinde bulunur. } \\
\text { - Alternatif enerji kaynaklarını tanır. } \\
\text { - Nükleer enerji kullanımını bilim, toplum, } \\
\text { teknoloji, çevre ve ekonomi açısından } \\
\text { değerlendirir. } \\
\text { - Sürdürülebilir hayat ve kalkınmanın toplum ve } \\
\text { çevre için önemini kimya bilimi ile } \\
\text { ilişkilendirerek açıklar. } \\
\text { - Nanoteknoloji alanındaki gelişmeleri bilim, } \\
\text { toplum, teknoloji, çevre ve ekonomiye etkileri } \\
\text { açısından değerlendirir. }\end{array}$ \\
\hline
\end{tabular}

\subsection{Meslek Lisesi Öğretim Programlarında Çevre Ĕ̈itimi}

Mesleki ve Teknik Eğitim Öğretim Program'ları incelendiğinde, çevre konularıyla ilgili kazanımlara 9. sınıflarda Coğrafya, Biyoloji, Kimya, Sağlık Bilgisi ve Trafik Kültürü dersleri içeriğinde yer verildiği ve tüm liselerde bu derslerin ortak olarak okutulduğu görülmektedir. Ayrıca 9. sınıf alan ortak dersi olan 'Mesleki Gelişim' dersi içerisinde de çevre konularına 5 ders saati ayrılmakta, çevre kirliliği, çevreye zarar vermeyen enerji kaynakları kullanımı, çevreyi koruma ve israfı önleme gibi kazanımlara yer verilmektedir.

Mesleki ve Teknik Eğitim Öğretim Program'ları içeriğindeki ‘Aile ve Tüketici Hizmetleri’, 'Meteoroloji ve Yenilenebilir Enerji Teknolojileri' alanlarında çevre konuları kapsamlı bir şekilde ele alınmakta ve bu konular farklı ders başlıkları şeklinde nitelendirilmektedir. 'Aile ve Tüketici Hizmetleri' alanındaki programdaki 'Çevre Hizmetleri' dalı kapsamında; 'Yaşadığımız Çevre', 'Atıklar', 'Toprak ve Su Kirliliği', 'Hava Kirliliği', 'Gürültü ve Radyasyon Kirliliği', 'Geri 
Dönüşümlü Ambalajlar' dersleri bulunmakta ve çevre konularına ait kazanımlar da bu dersler içerisinde yer almaktadır.

Meteoroloji alanı Öğretim Program'ı içerisinde ise 'Tarımsal Meteoroloji', 'Klimatoloji', 'Aeroloji', 'Hava Analiz ve Tahmin Tekniği' dersleri adı altında çevre kazanımlarına yer verilmektedir. Son olarak 'Yenilenebilir Enerji Teknolojileri' alanı programı incelendiğinde 'Rüzgar Enerji Sistemleri' ve 'Güneş Enerji Sistemleri' dallarının bulunduğu ve bu dallara ait derslerin çevreye zarar vermeyen yenilenebilir enerji teknolojilerinin kurulumu, işletilmesi, bakımı ve onarımı gibi kazanımlar içerdikleri görülmektedir (Mesleki ve Teknik Eğitim Öğretim Programları, 2019).

\section{Yaygın Ĕ̈itimde Çevre Ĕ̈itimi}

Çevre eğitimi sadece örgün eğitimi kapsamayan, hayat boyu devam etmesi gereken disiplinlerarası bir eğitimdir (Doğan, 1998; Kabaş, 2004). Yaygın eğitim, hayat boyu öğrenme içerisinde yetişkinlere yönelik, eğitim hizmetlerinin tümünü kapsayan bir alt sistem olarak kabul edilmektedir. Yaygın eğitim okul hayatı bitmiş veya hiç okula gitmemiş bireylerin ihtiyacını karşılamaya yönelik bir eğitim anlayışıdır. Bilindiği gibi yaşanılan çevreye dair öğrenme hayat boyu sürdügü ve bu süreçte çevre eğitimi büyük önem taşıdığı için yaygın eğitim içerisinde de çevre eğitimine yer verilmesi gerekliliği kaçınılmazdır (Kabaş, 2004; Özoğlu, 1993).

Bütüncül bir eğitim süreci içerisinde özel sektör ve kamu çalışanları, yöneticiler, işçiler yani tüm insanlar ayrım gözetilmeksizin çevre eğitimi almalıdır (Ilgar, 2007; Kiziroğlu, 2000). Yaygın eğitimde, bireyin yaşadığı çevrenin sorunları hakkında bilinçlenmesi, çevreyi koruma, çevre sorunlarına çözüm önerileri geliştirme gibi farkındalığının artırılmasını sağlayacak konulara yer verilmesi gerekmektedir (Ilgar, 2007; İleri, 1998). Yaygın eğitimde uygulanacak programların; çevre sevgisini geliştirme, çevreyi korumaya katkı sağlatma, duyarlılık seviyesini arttırma gibi çağdaşlık seviyesinde program içerikleriyle hazırlanması tavsiye edilmektedir (Kabaş, 2004; Nazlığlu, 1991).

Yaygın eğitimin çevre eğitimi açısından amaçları şu şekil sıralanabilir:

- İnsanların yaşadığı çevredeki sorunlara vakıf olması ve bu konuda farkındalık geliştirmesi,

- Bireyin içinde yaşadığı çevreye dair sorunlara yönelik belirleyici rol üstlenmesi,

- Sürdürülebilir bir hayat için kendisinin ne gibi katkılarının olabileceğinin farkına varması,

- Çevresindeki insanları bu konuda bilgi sahibi edebilmesi,

- Edindiği bilgileri uygulamaya dökmesi (Ilgar, 2007).

Günümüzde hizmet veren bazı yaygın eğitim kurumları; özel kurslar ve dershaneler, çıraklık eğitim merkezleri, halk eğitim merkezleri, bilim ve sanat merkezleri, açık öğretim merkezleri olarak siralanabilir.

Ayrıca belli zaman aralıklarıyla yetişkinlere yönelik bazı etkinlikler de düzenlenmektedir. "Kırsal Çevre ve Ormancılık Sorunları Araştırma Derneği" 1992 yılından bu yana "Dendroloji (Ağaçbilim) ve Orman Ekolojisi Okulu" programıyla ücretsiz olarak 100 kişiye eğitim vermektedir. Bunun yanı sıra Özel Çevre Koruma Müdürlüğü, yerel halkın çevre konusunda bilgi sahibi olabilmesi için "Çevre Koruma Eğitimi", vermektedir. T.C. Çevre ve Ormancılık Bakanlığı (günümüzde T.C. Orman ve Tarım Bakanlığı; T.C. Çevre ve Şehircilik Bakanlığı) ise gerektiği kadar su kullanma, ağaçlandırma, yangınlarının önlenmesi konularında "Seyyar Araçta Çevre Eğitimi" uygulamıştır (Kesercioğlu, 2010). TEMA (Türkiye Erozyonla Mücadele Ağaçlandırma ve Doğal Varlıkları Koruma) Vakfı, TSK(Türk Silahlı Kuvvetleri), İçişleri, Diyanet İşleri, Milli Eğitim Bakanlığı (MEB), Yerel Yönetimler ve Özel Sektörü kapsayan yetişkin eğitimleri faaliyetlerine (Erozyonla Mücadele seminerleri, Yeşil Yaka programı, Ekolojik Okuryazar Öğretmen Ĕgitimi programı, Ekolojik Okuryazar Yerel Yönetim programı vb.) devam etmektedir (Türkiye Erozyonla Mücadele Ağaçlandırma ve Doğal Varlıkları Koruma Vakfi, 2020). 


\section{Çevre Eğitiminde Çağdaş Yaklaşımlar}

Geçmişten günümüze kadar geçen süreçte insan ihtiyaçları sürekli değişmektedir ve değişen bu ihtiyaçların oluşturduğu etkiye karşı doğanın da bir tepkisi olmaktadır. İnsanların ve sorunların bu etki-tepkisi değiştikçe çözümde de değişime gidilmesi gereği ortaya çıkmaktadır. Bu da ancak insanın mevcut bulunduğu ortamını tanıması, bu ortamdaki mevcut ve olası sorunların çözümünde aktif katılım sağlaması, çevresindeki değişimleri fark etmesi ve çevreye yönelik yeni davranışlar kazanmasıyla mümkün olabilir (Başaran, 1977; Yılmaz, 2016 Bireyi bu değişim sürecine adapte etmek ise ancak insanda davranış değişikliği yaratmayı amaçlayan nitelikli ve iyi planlanmış bir çevre eğitimi ile gerçekleştirilebilir. Sauve 2005 yılında hazırladığı bir çalışmada, çevre eğitimi yaklaşımlarının geleneksel ve çağdaş yaklaşımlar olarak ikiye ayrıldı̆̆ını belirtmektedir. Söz konusu ayrımda geleneksel yaklaşımlar, sadece insan ile doğa arasındaki ilişkiyi ele almakta ve ağırlıklı olarak fen alanını kapsamaktayken, çağdaş yaklaşımlarda çevre bütüncül ve sosyokültürel bir açıdan değerlendirilmekte ve buna dayanılarak çağdaş yaklaşımların eyleme yönelik ve sürdürülebilir olduğu düşünülmektedir. Özetle çağdaş yaklaşımlarda çevre eğitiminin yalnızca fen boyutu olmadığ 1 , sosyal ve kültürel boyutunun da aynı oranda etkili olduğu kabul edilmektedir (Çevre Bakanlığı, 1998; Özdemir, 2007; Sauve, 2005; Yılmaz, 2016), (Şekil 1).

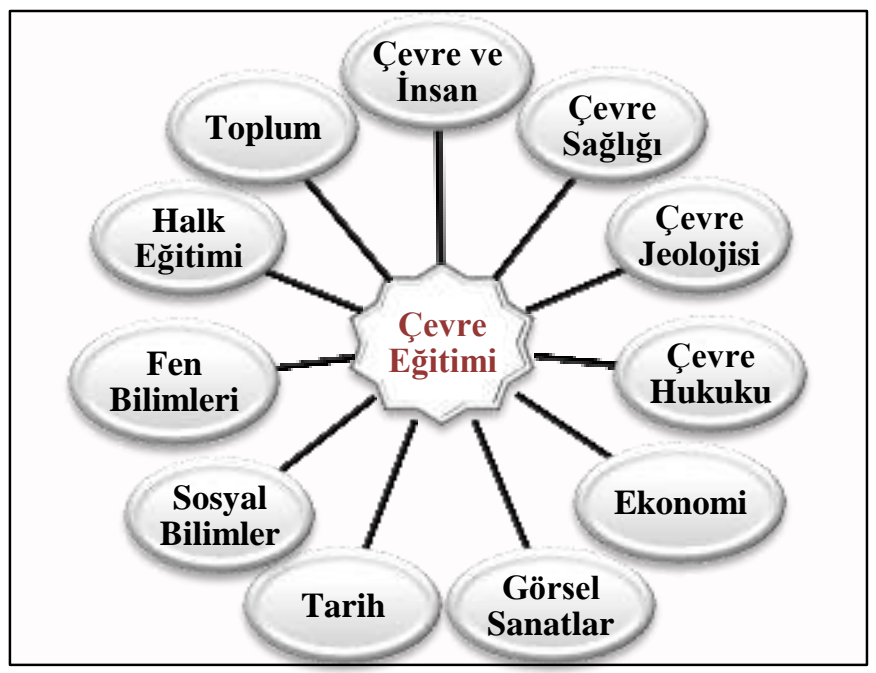

Şekil 1: Çevre Eğitimi Çok Boyutludur ve Disiplinler Arası Bir Yaklaşıma Sahiptir

Çevre eğitimi dersinden istenen verimin alınabilmesi için farklı yöntemler uygulanması gerekliliği günümüzde artık kabul edilmiş bir durumdur. Çünkü çevre konusunda duyarlı ve bilinç düzeyi yüksek bireylerin yetiştirilmesi ancak öğrenciyi aktif hâle getiren, ezber yapmaktan kurtaran ve beyin gücünü geliştirmeyi sağlayan modern öğretim yaklaşımlarının kullanılması ile mümkün olabilmektedir. Çevre eğitimi alanında gerçekleştirilen çalışmalar göz önüne alındığında bilim insanlarının bu eğitimden alınan verimi arttırabilmek amacıyla sürekli olarak yeni yaklaşım önerileri sundukları görülmektedir. Benimsenen yaklaşım doğrultusunda ise uygulanan çevre eğitiminin belirlenmiş hedefleri ve işleyiş biçimleri farklılıklar gösterebilmektedir (Çevre Bakanlığı, 1998; Özdemir, 2007; Yılmaz, 2016). Aşağıda çevre eğitiminde ön plana çıkan bazı çağdaş yaklaşımlar başlıklar halinde irdelenecektir (Şekil 2). 


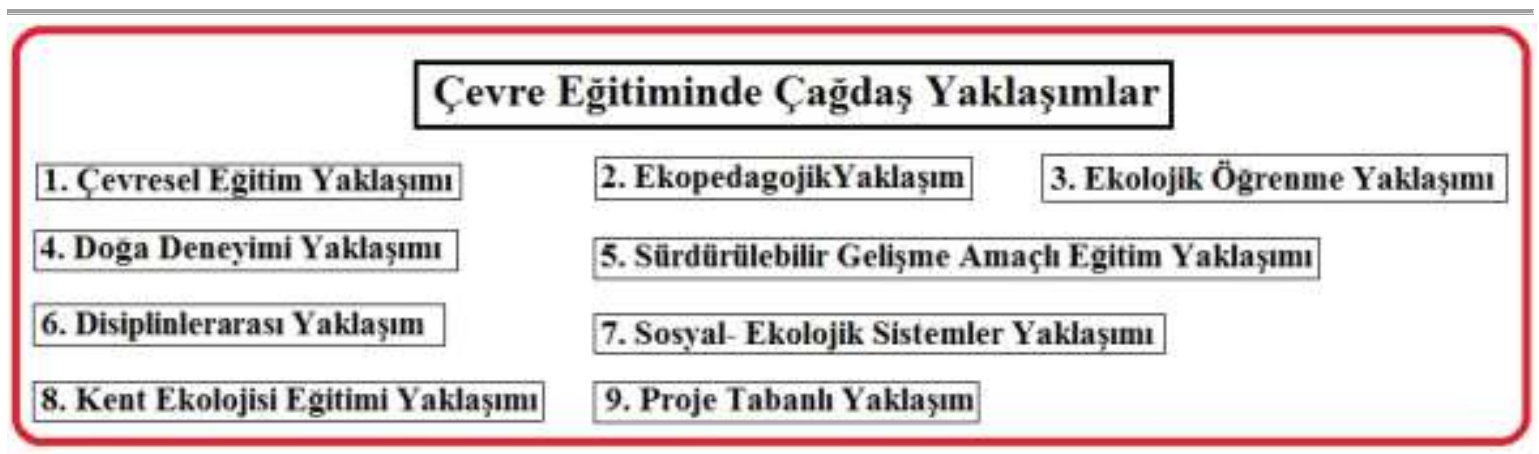

Şekil 2: Çevre Eğitiminde Bazı Çağdaş Yaklaşımlar

\section{1. Çevresel Eğitim Yaklaşımı}

Çevre eğitimi için ilk yıllarda benimsenen çevresel eğitim yaklaşımı, fiziksel ve sosyal sistemlerin etkileşimlerinin öğrenilmesini amaçlamıştır. Fakat bu süreçte eğitimin fazlasıyla teknik ve araçsal kalmasına bağlı olarak toplumsal kaynaklı çevresel sorunları göz ardı etmiş, sonuç olarak yerini ekopedagojik yaklaşıma bırakmıştır (Çelikbaş, 2016; Özdemir, 2007).

\section{EkopedagojikYaklaşım}

Ekopedagoji, çevre eğitimine eleştirel ve politik bir bakış açısıyla bakılmasını sağlamış ve temelinde doğaya, insana, kültüre ve çeşitliliğe saygıyı barındıran bir anlayış olmuştur (Gronemeyer 1987; Kahn 2010; Okur Berberoğlu, 2015). Bu anlayışa göre insan kendi türüne sayg1 gösterirken aynı zamanda doğaya da saygı göstermeli ve 'daha iyi insan olmak' amaciyla hareket etmelidir. Ekopedagoji ile çevresel okur yazarlığın ve sürdürülebilir bir yaşamın sağlanabileceği savunulmuştur. Ekopedagoji yaklaşımlı bir çevre eğitiminin amacı; ekoloji prensiplerini temel alan bir eğitim ile yaşam kurallarını benimsetmek ve bu kuralları kalıcı tutum ve davranışlara dönüştürmeyi sağlamaktır (Atasoy, 2005; Gronemeyer,1987; Kahn 2010; Okur, 2012).

\section{Ekolojik Öğrenme Yaklaşımı}

Ekolojik felsefe, bireyin doğa ile karşılıklı etkileşim içinde olmasını ve doğadan faydalanırken doğanın isteklerinin de göz önüne alınması gerektiğini savunur. Ekolojiyi temele alarak yapılan bir eğitim bireyin çevre ve bilime dair bilgileri öğrenmesinde en etkili yöntemdir (Ozaner, 2004; Phenice ve Griffore, 2003; Thoe ve Lin, 2006).

Ekolojik öğrenme yaklaşımı, bireyin içinde bulunduğu çevreyi ve sosyal ortamının farkına varmasını sağlayarak, çevre eğitiminin insanda ve toplumda değişime öncülük yapması gerektiğini vurgulamış ve "yeni bir insan, yeni bir toplum" düşüncesini benimsemiştir. Yaklaşımın akademik olarak yetersiz olması ve uzmanlaşmayı dikkate almamasından dolayı etkililiği azalmıştır (Çetin, 2018; Özdemir, 2007).

\section{Doğa Deneyimi Yaklaşımı}

Günümüzde kentleşme oranının artması çocukların doğa ile girdiği etkileşimi azaltmakta ve doğaya farklı anlamlar yüklemelerine sebep olmaktadır. Deneyimleyemedikleri bu doğa onlara bazen korkutucu bazen ütopik bazen de romantik gelir. Çocuklardaki bu algının değişmesi için doğa ile bağlarının sıkılaştırılması, doğayla birebir etkileşimde olmaları, yaparak ve yaşayarak deneyimler kazanmaları ve aktif olarak doğanın içinde yer almaları gerekmektedir. Bu bağlamda gerçekleştirilecek olan bir çevre eğitiminin sadece okul içi eğitim programlarına bağlı kalmayıp okul dışı programlarla desteklenmesi çocukların doğaya yükledikleri anlamların farklılaşmasına ve doğanın değerinin anlaşılmasına neden olacaktır. Yapılan araştırmalarda da doğadan bağımsız bir şekilde gerçekleştirilen çevre eğitimi sonucunda öğrencilerin doğal çevrelerini yeterince iyi tanıyamadıkları ve buna bağlı olarak çevrelerine karşı bilinçli davranışlar sergileyemedikleri belirlenmiştir (Özdemir, 2010; Pasl1, 2019). 
Doğa deneyimine dayalı çevre eğitimi öğrencilerin biyoçeşitlilik, canlı ve cansız varlıklar arası ilişki, madde döngüleri, besin akışı gibi ekolojik olayları kendi başlarına keşfederek daha da iyi kavramaları açısından oldukça önemlidir (Özdemir, 2010; Özdemir ve Uzun, 2006). Doğa eğitimleri sayesinde insanın doğaya müdahalesinin nasıl olduğunu ve bu müdahale sonucunda meydana gelen değişikliklerin öğrencilerin öğretilmesi doğayı daha çok sevmesini ve benimsenmesini sağlayacaktır. Yapılacak doğa eğitiminin özellikleri arasında; birey ile doğa arasındaki ilişkiyi güçlendirmek, aktif öğrenmenin gerçekleşmesi, öğrenme aşaması içerisindeyken keyif verici ve ilgi çekici olması gibi özellikler bulunmaktadır (Birinci, 2013; Bullock, 1994). İlk ve ortaöğretim çağındaki çocukların bütünselliği anlamalarına yardımcı olan bu eğitim, çocukların doğanın bir parçası olduklarını ve doğaya verebilecekleri her türlü zarardan kendilerinin de etkileneceğini kavramalarını sağlarken gelecekte de çevre değerlerine önem veren, hassasiyet gösteren bireyler olmalarını amaçlamaktadır (Kaskens vd., 1999; Louv, 2008; Özgel, Aydoğdu ve Güven Y1ldırım, 2018).

\section{Sürdürülebilir Gelişme Amaçlı Ĕ̈itim Yaklaşımı}

Sürdürülebilirlik kavramı Latince "sustinere" kelimesinden gelmektedir ve sözlüklerde birçok anlamda karşımıza çıktığı halde, esas olarak; 'devam ettirmek, sağlamak, desteklemek' anlamlarında kullanılmaktadır (Ergün ve Çobanoğlu, 2012; Onions, 1964). Sürdürülebilirlik düşüncesi yeryüzünde var oluşun devamlılığı şeklinde ele alınarak insan egemen anlayışın doğaya zarar verdiği fark edilmiş ve sürdürülebilir kalkınma anlayışı oluşmaya başlamıştır.

Sürdürülebilir kalkınma 1987'de yayımlanan 'Ortak Geleceğimiz' raporuna göre; gelecek kuşakların kendi ihtiyaçlarını karşılayabilme olanaklarını ortadan kaldırmadan bugünün ihtiyaçlarını karşılamak şeklinde tanımlanmıştır. Sürdürülebilir kalkınma, yararcı yaklaşım açısından değerlendirildiğinde canlı ve cansız bütün çevrenin korunmasına katkı sağlayan, toplum yararını arttıran nitelikte olduğu görülmektedir. (Ergün ve Çobanoğlu, 2012; United Nations, 1987).

Sürdürülebilir kalkınma anlayışının ekolojik, sosyal ve bir de ekonomik olarak üç ayrı bileşeni bulunmaktadır. Ekolojik bileşeni, kaynakların kullanımı, biyolojik çeşitlilik, ekosistem bileşenlerinin korunması ve atmosferik denge gibi konuları içerirken sosyal bileşeni, insan odaklı olup, sosyal hizmetlerin yeterliliği ve adil bir şekilde dağılımı, politik sorumluluk ve katılımın gerçekleşmesi, cinsiyet eşitliği temalarını kapsamaktadır. Ekonomik bileşeninde ise, kaynakların kullanımı ile ilgili olan üretim ve tüketim faaliyetlerini, üretim esnasında üretime zarar verebilecek sektörel dengesizliklerden kaçınmayı, hükümet ve dış borçların yönetilmesi gibi konuları ele almaktadır (Tıraş, 2012).

Sürdürülebilir gelişme amaçlı eğitim, insanların sürdürebilir gelişme bilincini kazanıp eyleme geçirebilmeleri için güdülendiği, gelecekteki olayları tahmin edebilme ve karar verebilme olgunluğunu kazandıran, eleştirel düşünmeyi sağlayan, katılımcı öğrenme yöntemlerinin özümsendiği bir yaklaşım olarak tanımlanmaktadır (Öztürk, 2017; United Nations Educational Scientificand Cultural Organization, 2014). Sürdürülebilir gelişme amaçlı eğitimin, yeni yaşam olanaklarına, üretim ve tüketim şekillerine ve birlikte yaşam biçimine öncelik vermesi, sürdürülebilirliğin ekonomik, sosyal ve ekolojik boyutları arasındaki ilişkileri temel alması ve yapılandırmacı öğrenme düşüncesine dayanması geleneksel çevre eğitimini anlayışından ayrılmasına neden olmaktadır (Gräsel, 2002; Özdemir, 2007).

Sürdürülebilir gelişme amaçlı çevre eğitiminin temelinde çevre hakkında eğitim, çevre içinde eğitim ve çevre için eğitim olmak üzere üç farklı yaklaşımdan bahsedilmektedir (Mamur, 2017; Okur Berberoğlu ve Uygun, 2013). Çevre hakkında eğitim, insan-çevre ilişkileri hakkında bireyleri bilgi sahibi yapmak, neden-sonuç ilişkilerini anlatmak ve ilgi düzeylerini arttırmaya yönelik, daha çok bilişsel alanı geliştirmeyi amaçlayan bir yaklaşımdır (Mamur, 2017; Tilbury, 1995). Çevre içinde eğitim, sınıf dışında, öğretmen merkezli öğretimden daha çok öğrencinin aktif katılım sağladığı ve yapılan etkinlikleri merkeze alan eğitimler olarak karşımıza çıkmaktadır (Mamur, 2017; Tilbury, 1995). Çevre için eğitimde ise bireylerin sorumluluk duygularının 
gelişmesi ve çevresel problemlere çözüm sağlanırken aktif katılımcı olarak rol almaları hedeflenmektedir (Mamur, 2017; Okur Berberoğlu ve Uygun, 2013).

Özdemir (2007) sürdürülebilir gelişme amaçlı eğitimde benimsenecek ilkeleri; disiplinler arasılık, süreklilik, kapsayıcılık, bütünsellik, esneklik, katılımcılık, tutumluluk, devamlılık ve doğaya uygunluk, sorgulayıcılık, yaşantısallık, küresellik-yerellik, verimlilik ve etkinlik, yenilikçi öğrenme, yaparak-yaşayarak öğrenme, yapılandırmacı (oluşturmacı) öğrenme ve öngörüsel öğrenme şeklinde sıralamıştır. Bu hedefler sürdürülebilir gelişme amaçlı eğitime yön verecek aynı zamanda sürdürülebilir bir yaşamın koşullarını sağlayan temel stratejiyi oluşturacaktır (Özdemir, Özkan ve Özgen, 2006; Özdemir, 2007).

Sürdürülebilir gelişmeyi amaçlayan eğitimde güdülenmesi gereken amaçlar; çevre hakk1 ve mesuliyetin kazanılması, çevre gözlemleri yapılarak incelenmesine yönelik yöntemin kazandırılması, ekolojik ilişkilerin anlaşılması, çevreye yönelen ekonomik, ekolojik ve sosyal etkilerin fark edilmesi, canlıların yaşam alanlarının ve nesillerinin korunması sadece günümüz için değil geleceğimiz için olduğunun kavranılması ve bütün fertlerin ve toplumun çevreye karşı sorumlu ve duyarlı davranışlarının artmasının yaşamın temelleri olduğunun anlaşılması şeklinde siralanmaktadır (Klautke ve Kohler, 1991; Özdemir, 2007).

Sürdürülebilir gelişme amaçlı eğitimde biliş ve anlayış eğitimi yanı sıra duyuş eğitimi de oldukça dikkate alınmakta, öğretim süreci boyunca bireyin duygu dünyasını besleyen estetik bir uyanışa sebep olması beklenilmektedir. Eğitim süreci, estetik uyanış sağlayan ve yaratıcılığı geliştiren sanat ürünleriyle zenginleştirilmesiyle öğrencilerde çevre hassasiyetini artırıcı şekilde ortaya konulması, duyuş eğitiminin çevre eğitiminde ve sürdürülebilir gelişme amaçlı eğitimde öneminin ne kadar fazla olduğunu göstermektedir (Özdemir, 1998; Özdemir, 2007).

\section{Disiplinler Arası Yaklaşım}

Çevre kavramı beşeri, siyasi, psikolojik, felsefi, teknolojik, ahlaki, ekonomik ve kültürel gibi birçok boyuta sahip olan disiplinler arası bir kavramdır. Buna bağlı olarak çevre eğitimi de fen, sosyal, matematik ve daha birçok alanla ilişkisi olan disiplinler arası bir alandır. Çevre eğitiminde istenilen amaç ve hedeflerin gerçekleştirilebilmesi için önerilen iki yaklaşım; çok disiplinli yaklaşım ve disiplinler arası yaklaşım olarak bilinmektedir. Disiplinler arası yaklaşım faklı alanların konularını içine alan, onların tek ders içinde, bütüncül ve anlamlı bir şekilde verildiği yaklaşımken çok disiplinli yaklaşım, çevre eğitiminin farklı alanlar içerisinde verildiği yaklaşımdır (Çetin, 2018; Güven, 2012; Hungerford ve Peyton, 1994).

Disiplinler arası yaklaşımın olumlu ve olumsuz özellikleri:

- Disiplinler arası yaklaşımda tek bir derste istenilen diğer tüm konuların verilmesi uygulamada pratiklik sağlamaktadır.

- Birden fazla disiplinin bir arada olması öğreticilerin de bu konulardaki yeterliliklerinin yüksek olmasını gerektirir.

- Çevre eğitimi gibi söz konusu alanın içeriğinde çok fazla boyut varsa disiplinler arası yaklaşımla ele almak avantaj sağlar.

- Program içerisindeki bileşenleri açıklamak, yerleştirmek ve geniş alanlı bir değerlendirme yapmakta kolaylık sağlar.

- Öğrenilen bilgilerin başka bir durum veya canlıya aktarılması ekstra bir uğraş gerektirir.

- Gerekli araç, gereç veya etkinlikler için ekonomik alt yapı gerekmektedir (Çetin, 2018; Hungerford ve Peyton, 1994).

Disiplinler arası yaklaşım ele alınarak yapılan bir öğrenim her disiplinden biraz işlemek anlamına gelmemekte, dersin içerisinde verilecek konunun farklı disiplinleri birleştirerek dengeli ve bütüncül olarak aktarılmasını anlatmaktadır. Bu doğrultuda birbirinden farklı gibi görülen disiplinlerin aslında birbiri ile ne kadar ilişkili olduğu fark edilmektedir. Birden fazla disiplinin yer alması ögrencilerin bir disiplini sevmese bile diğer disiplin ile alakadar olmasından dolayı derse olan ilgisini devam ettirir. Ülkemizdeki öğretim programları içindeki derslerin içeriğinde verilen çevre eğitiminde ise disiplinler arası yaklaşımın göz ardı edildiği görülmektedir. Hayat Bilgisi, Fen 
Bilimleri ve Sosyal Bilgiler gibi çevre eğitimi konularını içeren derslerde, birbirinden bağımsız parçalar şeklinde çevre eğitimi verilmeye çalışılmaktadır (Çetin, 2018; Güven, 2012).

Disiplinler arası bir öğretimde daha çok probleme dayalı öğrenme gerçekleştirilmektedir. Güncel hayattan uzak bir şekilde geleneksel olarak verilen eğitim, disiplinler arası yaklaşımla günlük hayatımıza entegre edilmektedir. Yaşamımızda bir problem haline gelen çevre sorunlarının nedenleri ve çözümlerinde birçok disiplinin kullanılması, çevre eğitiminde disiplinler arası yaklaşımın gerekliliğini ön plana çıkarmaktadır (Güven ve Hamalosmanoğlu, 2012; Yıldırım, 1996).

\section{Sosyal-Ekolojik Sistemler Yaklaşımı}

Çevre duyarlılı̆̆ının oluşmasının ve sorunlara çözüm yolları üretmenin bireysel ve toplumsal yönlerini içeren yaklaşıma "sosyal-ekolojik sistemler yaklaşımı" ismi verilmektedir (Alagöz, 2010; Kyburz-Graber vd., 1997). Sosyal-ekolojik sistemler çevre eğitiminin temelini oluşturur. İnsanın doğa ile bütün olduğunu belirten bu sistemde sürdürülebilirliğin sağlanması ana hedeftir. Sürdürülebilir kalkınmanın önemi vurgulanırken eğitimcilerin vereceği çevre eğitiminin sosyal konularla bütünleştirilmesi istenir (Alagöz, 2010; Krasny ve Tidball, 2008). Öğrencilerin öğrenim süreci boyunca sosyolojik sistemleri araştırırken, çevreye dair sorunların ekonomik ve sosyal yönlerini kavramaları, bu yönler arasındaki bağlantıları keşfetmeleri amaçlanmaktadır (Alagöz, 2010; Kyburz-Graber vd., 1997).

Sosyal-ekolojik sistemler yaklaşımının iki yönü bulunmaktadır. İlki genel eğitim sistemi içerisindeki çevre eğitiminin yeri ile ilgili olup ikincisi ise çevre eğitiminin sürdürülebilir bir toplumun bileşeni olmasıdır (Çetin, 2018; Kyburz-Graber vd., 1997). Eğitim sistemi içerisindeki çevre eğitimi, öğrencilerin sorumluluk sahibi, eleştirel düşünebilen ve kendilerini geliştiren bireyler olmalarını hedeflemektedir. Dünyanın temel sorunlarından biri olan çevre sorunlarına yönelik çözüm önerilerinin, öğrencilerin günlük yaşamlarında bu sorunlardan nasıl etkileneceğinin anlatılarak verilmesi gerekmektedir. Bu yaklaşım sürdürülebilir toplum olma yolunda çevreye zarar verecek sosyal yaşam tarzının değiştirilmesini önerir. Doğa bilimlerini tek başına yeterli görmeyip sosyal grupların, işletmelerin ve toplumların nasıl değiştirileceğini ve bu değişimin gerekli olup olmadığını sorgular (Alagöz, 2010).

\section{Kent Ekolojisi Ĕ̈itimi Yaklaşımı}

Kent çevreciliği yaklaşımı sosyal-ekolojik çevre eğitimi yaklaşımına paralel olarak ortaya çıkan yeni bir çevrecilik anlayışıdır. Krasny ve Tidball (2009) çevre eğitiminde kent yaşamına dair sosyo-ekolojik bir yaklaşım önermiş, bu önerdiği yaklaşıma kent ekolojisi adı verilmiştir. Kent çevreciliği ekolojik değerleri birleştirmeyi, bozulmamış alanları korumayı amaçlamakta olup çevreci bir kent oluşturma adına ağaç dikme, doğayı onarma gibi yapıcı eylemler gerçekleştirilmektedir.

Kent ekolojisi eğitiminin sürdürülebilir bir çevre eğitimine destek sağlayacağ 1 düşünülmektedir. Kent ekolojisi eğitimi bireyden topluma şeklinde uygulanmakta olup eğitim programları insan-doğa etkileşimiyle başlayarak, toplum ve ekosistem etkileşimine olumlu dönüt yaratmaktadır (Alagöz, 2010; Çetin, 2018; Kransny ve Tidball, 2008).

\section{Proje Tabanlı Yaklaşım}

Sürdürülebilir eğitim içeriğiyle yeni yaklaşımlar arasında sayılan "Proje Tabanlı Öğrenme Yaklaşımı"nın temelleri aslında 20. yüzyılın başlarında Dewey'in "Yeniden Yapılanma", Klipatrick'in "Proje Yöntemi", Bruner'in "Buluş Yoluyla Öğrenme Yaklaşımı", Thelen'in grup araştırması modelleri ile atılmaya başlanmıştır (Kızı1, 2012; Korkmaz, 2004).

Proje tabanlı yaklaşım, uzun bir araştırma süreci, dikkatli bir şekilde hazırlanmış projeler ve bu projelerle ilgili verilen çeşitli görevlerle, öğrencilerin bilgi, deneyim ve becerilerini öğrenme alanının içinde barındıran sistematik bir yaklaşım olarak kabul edilmektedir. Projeler mevcut bir problemle bağlantılı dinamik sorular ve bu soruların her yönüyle araştırılmasını gerektiren bir süreci temsil eder. Projeler çoğunlukla iş birlikli gruplar içermektedir ve bu durum öğrencilere 
kavramları öğrenmeleri, aktif araştırma yapmaları, bilgileri uygulama ve çeşitli şekillerde sunmaları için bir firsat sağlar (Elder, 2003). Proje tabanlı öğrenme, sınıf içinde gerçekleştirilen kısa süreli ve öğretmeni merkeze alan öğrenme biçiminde ziyade, uzun süreli, disiplinler arası, öğrenciyi merkeze alan ve gerçek dünya sorunlarının uygulamalarıyla harmanlanmış öğrenme etkinliklerini içeren bir sınıf modelidir. Aslında proje tabanlı öğrenme yaklaşımı tek başına değil, diğer birçok öğretim yöntemiyle birlikte kullanılabilen çok yönlü bir yaklaşım olarak bilinmektedir (Korkmaz ve Kaptan, 2001).

Öğrenciler proje hazırlık ve çalışma sürecinde; bir hedef belirleme, uygun bir plan hazırlama, şartları değerlendirme, aktif rol alma, kendine güvenme ve risk alma gibi etkili davranışlar geliştirmek durumundadırlar (Mansoor ve Moss, 1997). Proje tabanlı öğrenme süreci, öğrencilere soru yazma ve bu soruların cevaplarını bulma gibi imkanlar sunarken, öğrencilerin kendi öğrenmeleri için neler yapmaları gerektiğini keşfetmelerini de sağlamaktadır. Şahin (2004)'e göre proje tabanlı öğrenme yaklaşımının dört temel aşaması bulunmaktadır: çevreyi gözlemleme ve araştırma yoluyla uygun sorular bulma, bu sorulara etkili çözüm yolları üretme, soruları çözerek bir ürün ortaya çıarma ve tamamlanan projeyi sunarak başkalarıyla paylaşma. Proje sonuçlarının paylaşımı yazılı rapor veya sözlü sunum yollarıly gerçekleştirilebilmektedir (Benzer, 2010; Hansen, 2004; Prince ve Felder, 2007).

Proje tabanlı öğrenme bireylerde ve toplumda çevre kavramını içselleştirmek ve gelişmesini sağlamak için son derece önemli bir yaklaşım olarak benimsenmektedir. Çünkü proje temelli yaklaşımın çevre okuryazarlığı ile mükemmel bir uyum gösterdiği düşünülmektedir. Buna rağmen öğreticide proje tabanlı öğrenmeyi tercih etmek için gönüllülük, motivasyon ve öğrencileriyle bu denli karmaşık bir çalışmaya girişmek için yeterli bilgi ve donanım mevcut olmadığında uygulanması zor bir yaklaşım sayılabilir. Ayrıca sürecin uzaması, öğrencilerin motivasyonlarının azalması, konunun dağılması gibi bazı dezavantajlı durumlar da yaşanabilmektedir (Benzer, 2010; Elder, 2003; Kızıl, 2012; Korkmaz, 2004).

\section{Nasıl Bir Çevre Ĕgitimi?}

Çevresel sorunların küresel boyutlara ulaştığı günümüzde insan ile çevre arasındaki dengeli ve adil paylaşımın yeniden sağlanabilmesinin ancak eğitilerek belirli bir bilinç seviyesine erişmiş bireylerle mümkün olabileceği unutulmamalıdır. Çevre eğitimine yapılan yatırım geleceğin bireyleri olan çocuklarımızın bilinç seviyesini yükseğe taşımasıyla aslında temiz ve sürdürülebilir bir çevreye yapılan yatırım olarak görülmelidir. Özellikle son yıllarda eğitim ile mevcut çevre sorunları arasındaki bağlantı, okullarda verilen çevre eğitiminin yeterliliği, çevre duyarlılığı gelişmiş bireyler yetiştirmeye uygunluğu sıklıkla tartışılmaktadır. Sağlıklı ve devamlı bir çevre için eğitimin şart olduğu kabul edilirken, uygulanan eğitimin yeterliliği, işlevi ve özellikle uzun vadedeki etkilerinin irdelenmesinin gerektiği düşünülmektedir (Atasoy, 2005).

Çevre eğitiminde bilişsel ve duyuşsal amaçlar bulunduğu belirtilmiştir. Bilişsel amaçtan kasıt bireylerin bilinçli birer çevre okuryazarı olmasında rol oynamak iken, duyuşsal amaçtan kasıt bireylerde çevreye karşı olumlu yönde tutum ve davranışlar meydana getirmek ve bu yönü geliştirmektir. Çevre eğitiminde temel hedeflerden olan çevre okuryazarlığının, bireye kazandırılması hedeflenen bilgi, duyuş, davranış ve beceri olarak dört temel unsuru bulunmaktadır. Bunlardan ilki olan bilgi öğesi, ekoloji bilgisinin yanı sıra çevre hakkındaki terimlerin, tanımların, çevredeki olaylar ve bu olayların arasındaki ilişkinin kavranmasını nitelemektedir. Duyuş öğesi, bireyin çevreye ve çevredeki problemlere karşı duyarlılık kazanma ayrıca çevre ile ilgi davranışlarında sorumluluk taşıma ve bu sırada toplumun ahlaki ve etik değerlerini dikkate alma durumunu, davranış öğesi, bireyin çevre ile ilgili bilgi, tutum ve becerilerini somuta dökerek çevre sorunlarının çözümünde aktif olarak katılımını belirtmektedir. Beceri öğesi ise; kendisindeki bilgi ve becerileri çevredeki bir sorunun çözümünde kullanabilmesini ifade etmektedir (Erol, 2005; Roth, 1992), (Şekil 3). 


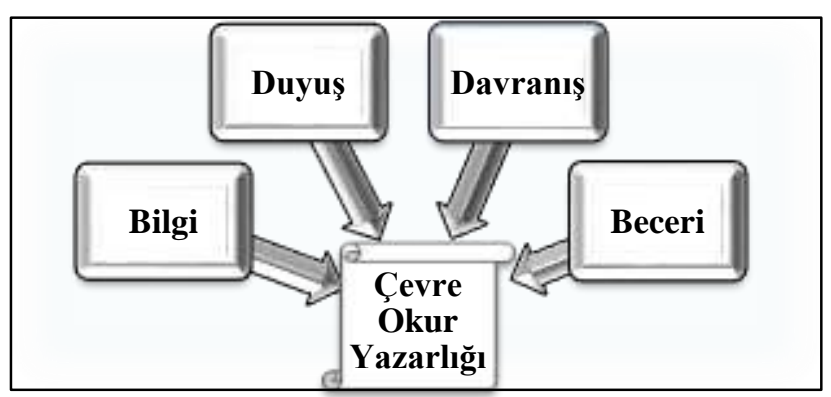

Şekil 3: Çevre Okuryazarlığı Bireye Dört Temel Unsuru (Bilgi, Duyuş, Davranış, Beceri) Kazandırmayı Hedeflemektedir

Çevreye yönelik görüşler arasında mekanist ve ekolojik görüşler ön plana çıkmaktadır. Mekanist görüş çevrede meydana gelen sorunların beşeri odaklı olmasından ziyade bu sorunların ancak bilim ve teknoloji ile çözülebileceğini savunur. Ekolojik görüş ise ortamda meydana gelen sorunların insan davranış ve tutumlarından kaynaklı olduğunu savunmaktadır. Çevre eğitiminin amaçlarını kapsayan ekolojik görüşün hedefi çevresinin ve çevreye olan etkilerinin farkında olan ve davranışlarında olumlu yönde değişim oluşturmuş birey yetiştirmektir. Çevre eğitimi belirli bir plana bağlı olmadan sürdürülen informal ve planlı bir şekilde sürdürülen formal (örgün, yaygın) olarak verilebilmektedir. Ülkemizde çevre eğitimi formal eğitim kapsamında örgün eğitim (okulöncesi, ilköğretim, ortaöğretim ve yükseköğretim) ve yaygın eğitim (kurslar ve hizmet içi eğitim) olarak da verilmektedir (Atasoy, 2006; Y1lmaz, 2016).

Çevre eğitiminin erken yaşta başlaması bireyin çevreye yönelik tutum, davranış ve bakış açısında etkili derecede farklılıklar yaratabilir. Çünkü çocukluk dönemlerinde kazandırılan değer yargıları ve verilen bilgiler çocuğun ileriki yaşantısında gerçekleştireceği istendik davranışlar için bir temel teşkil etmektedir. Erken dönemde çocuklara bu istendik davranışları kazandırmak amacıyla doğayla iç içe olabileceği oyunlar, doğa yürüyüşleri, bitki ve hayvan bakımı gibi uygulamalar yaptırmak onların doğa dostu, çevre bilinci gelişmiş birer birey olarak yetişmelerinde önemli bir rol oynayacaktır (Erten, 2004).

Ülkemizde yer alan eğitim sisteminin hedefi, girişimci, kararlı bir yapıya sahip, çevresiyle empati kurabilen, eleştirel düşünebilen ve sorunlara çözüm odaklı yaklaşabilen, çevresindeki sorunların farkında olup onlara çözüm üretebilecek bireyler yetiştirmektir. Bu hedefler doğrultusunda hazırlanan öğretim programlarının amaçları arasında çevre eğitimi de bulunmaktadır. Çevre eğitimi; bireylerin doğa ile etkileşim içinde olabileceği, çevre bilinci kazanmada rol oynayacak programlar hazırlamayı amaçlar (Sert Çıbık, 2019). 2005 yılından itibaren öğretim programlarımızda yer almaya başlayan çevre eğitimi; diğer bazı zorunlu derslerin içeriğine eklenerek verilmektedir (Akınoğlu ve Sarı, 2009; Alım, 2006).

Türkiye'deki eğitim sistemine bakıldığında çevreye yönelik içeriğin yetersiz kaldığı ve çevre eğitiminin sistemde bir parça haline gelemediği görülmektedir. Programlarımız ve çevre eğitiminin içerisinde yer alan kazanımların sürdürülebilirlikten ziyade sadece çevrenin tanıması ve korunmasını kapsadığı görülmektedir. Ülkemizde çevre eğitiminde istenilen başarıya ulaşılamamıştır. Bu durumun temel nedenlerinden birisinin eğitimin ne için ve nasıl verilmesi gerektiğinin bilinmemesi olduğu söylenebilir. Çevre eğitiminin içeriğinin, sadece çevreyi korumak, sevmek, tanımak ve öğrenmek olmaması gerekir. Öğretim esnasında verilen teorik bilginin yanında çevrede gerçekleşen bir sorun fark edilebilmeli ve farklı alanlar ile ilişki kurularak çevre bilinci geliştirmelidir (Tanrıverdi, 2009).

Demir ve Yalçın (2014) yaptığı bir çalışmada çevre eğitiminin programlarda yetersiz olarak ele alındığını belirtmiştir. Aynı çalışmada etkili bir çevre eğitimi için kazanım, zaman ve yer açısından uygun etkinliklerin sağlandığı, gerekli uygulamaların yapılmasına imkan verecek, doğa içerisinde yaparak yaşayarak gerçekleştirilen, yapılandırmacı yaklaşımın temele alınacağı, bütüncül ve disiplinlerarası bir program oluşturulması gerektiğini savunulmuştur. Ayrıca çevre eğitimini 
eğlenceli hale getirerek bilinçlenmeyi sağlayacak proje, beyin firtınası, gezi-gözlem, soru-cevap, drama, zihin haritası, metafor, analoji ve örnek olay yöntemi gibi birçok etkili teknikten yararlanılabilir (Demir, 2019; Gülay ve Önder, 2011).

\section{Sonuç, Tartışma ve Öneriler}

Günümüzde çevresel sorunlarla mücadelenin ancak çevre bilinci gelişmiş, çevreye karşı olumlu tutuma sahip bireylerle mümkün olabileceği kabul edilmiş durumdadır. Çevre bilinci söz konusu olduğunda ise gelecekte birçok önemli meslek grubunun başında bulunacak olan gençlerin çevre duyarlılığı yüksek bireyler olarak yetişmesini sağlayabilecek çevre eğitiminin değeri ortaya çıkmaktadır. Özellikle örgün öğretimde verilen eğitim, belli bir program dahilinde ve düzenli şekilde gerçekleştĭgi için çevre eğitimi açısından önemi göz ardı edilemez. Fakat okullarda çoğunlukla konuyu öğretmenin anlattığı, öğrencinin ise sadece pasif dinleyici olarak dahil edildiği geleneksel öğretim yöntemlerinin uygulanması örgün öğretimin verimliliğinin sorgulanmasını gerektirmektedir. Sadece öğretmenin aktif olduğu bir eğitim öğrenci için sıkıcı olmakla birlikte, çoğu öğretmenin kitaptan okumakla yetindiği konuları öğrenci ezberlemekte ve içselleştirememektedir. Böylesi bir eğitim sisteminden doğal olarak çevre eğitimi de etkilenmektedir.

Çevre eğitimi doğası gereği yaşayarak, deneyimleyerek öğrenmeyi gerektiren bir öğretim alanıdır. Çevre eğitiminin amaç ve hedeflerine ulaşması için bireyin motor becerilerine, bilişsel alanlarına, çevreye yönelik tutum ve değerlerine katkı sağlayacak, buluş ve keşif yolu gibi doğayla iç içe yenilikçi öğrenme süreçlerini içeren bir eğitim süreci gerekmektedir. Böyle bir süreç yürütebilmek için ilk adım olarak klasik öğretim yöntemlerinden çıkılarak öğrenci merkezli çağdaş öğretim yöntem ve tekniklerine yönelmek gereklidir (Bulut, 2015; Demir ve Yalçın, 2014; Özbuğutlu, Karahan ve Tan, 2014; Tanrıverdi, 2009).

Çevre eğitiminin geleneksel yöntemlerle işlenmesinin ve öğrenilen teorik bilginin uygulamaya dökülememesinin öğretimin verimini düşüreceği birçok araştırmacı tarafından belirtilmiştir (Aktepe ve Temur, 2018; Bilgi 2008; Dinçer, 1988; Mucunguzi, 1995; Ozaner, 2004; Özdemir, 2007; Rickinson, 2001). Erten'in 2003 yılında yapmış olduğu çalışmada gerçekleştirilen uygulamalı çevre eğitimi sonucunda öğrencilerin çevre bilinçlerinin arttı̆̆ 1 ve bunun davranışa dönüştügü tespit edilmiştir. Özgel ve arkadaşlarının (2018) çalışmasında ise 7. sınıf öğrencileri için doğa kampı destekli gezi-gözlem yöntemi kullanılmış ve çalışmanın sonucunda bu yöntemin geleneksel öğretim yöntemlerine göre çevre sorunlarına yönelik farkındalık oluşmasında daha etkili olduğu gözlemlenmiştir. 2008 yılına ait bir diğer çalışmada çevre eğitiminde aktif öğretim modeli uygulamasının, öğretmen merkezli çevre eğitimi ile kıyaslandığında, öğrencilerin çevre bilgi ve tutumları üzerinde daha olumlu etki gösterdiği ayrıca öğrencilerin bilişsel, sosyal ve duygusal yönlerden gelişmelerini sağladığı belirtilmiştir (Bilgi, 2008). Bu araştırmalar kapsamında da bakılacak olursa okulda gerçekleştirilen geleneksel eğitimin çevreyi tanımak ve anlamak için yeterli olmadığı, öğrencilerin ezberleyerek değil keşfederek öğrenmesinin çevre bilinci edinmelerinde daha etkili olduğu görülmektedir.

Ülkemizde 2018 yılından itibaren uygulamaya alınmış olan ilköğretim (ilkokul, ortaokul) ve ortaöğretim ders programları incelendiğinde çevre konularına ait kazanımlara ayrı bir ders olarak değil, Hayat Bilgisi, Fen Bilimleri, Sosyal Bilgiler, Coğrafya, Biyoloji ve Kimya gibi bazı temel derslerin öğretim programlarına entegre edilmiş olarak yer verildiği görülmektedir. Başka bir dersin içeriğine sıkıştırılmış olarak verilmeye çalışılan çevreye yönelik kazanımlar maskelenmekte, dolayısıyla yetersiz kalmaktadır. Ayrıca çevre kazanımlarını içeren ünite ve konular, çoğunlukla programların y1l sonuna denk gelen döneminde bulunduğu için öğrenciler tarafindan önemsiz olarak algılanmakta ve dikkate alınmamaktadır. Bazı öğretim düzeylerinde açılan çevre eğitimine yönelik derslerin ise seçmeli ders kategorisinde bulunduğu ve yeterli katılım olmadığı için açılmadığı bilinmektedir. Nitekim ortaokul 7. ve 8. sinıflara yönelik seçmeli ders konumundaki Çevre Eğitimi (2 saat) dersi ortaokul haftalık ders programında yer almasına rağmen genellikle öğrencilerce seçilmemektedir. 
Günümüzün en önemli sorunlarından birisi olan çevresel sorunların, ayrı bir ders başlığı altında toplanarak ciddiyetle uygulanması gerektiği konusunda birçok araştırmacı hem fikirdir (Bulut, 2015; Demir ve Yalçın, 2014; Erdoğan, Bahar ve Uşak, 2012). Uzun ve Sağlam (2007), gerçekleştirdikleri çalışmada ortaöğretim öğretim programlarında çevre eğitimi üzerine ayrı bir dersin bulunmadığını, dersin bazı okullarda seçmeli olarak verildiğini fakat yeterli öğrenci sayısına ulaşılamadığ 1 için açılmadığını ve buna bağlı olarak ortaöğretim kapsamında edinilmesi gereken çevre bilincinin oluşamadığını rapor etmişlerdir. 2009 yılında yayımlanmış bir başka çalışmada ise ilköğretim programlarında çevre eğitimi kazanımı yüzdesinin $\% 11,82$ olduğu belirtilerek Türkiye'de çevre eğitiminin uluslararası gelişmeler doğrultusunda düzenlenmeye ihtiyaç duyduğuna ve çevre eğitiminin ayrı bir zorunlu ders olarak okutulması gerektiğine dikkat çekilmiştir (Akınoğlu ve Sarı, 2009).

\section{Öneriler:}

Elde edilen veriler 1şı̆̆ında çevre eğitiminde verimin arttırılması için aşağıda belirtilen hususlara önem gösterilmesi önerilmektedir;

- Çevre eğitiminde çevrenin sadece fen boyutunda değil, doğal, yapay, sosyal, ekonomik, kültürel, politik, teknolojik, ahlaki, tarihi, psikolojik ve estetik birçok öğeden oluşan bir bütün olarak ele alınması sağlanmalıdır. Finlandiya, İrlanda gibi bazı Avrupa ülkelerinin öğretim programlarında çevre kazanımları görsel sanatlar ya da tarih gibi dersler içerisinde de ele alınmaktadır (Tanrıverdi ve Kablan, 2008; Tanrıverdi, 2009).

- $\quad$ Çevre eğitiminde ezbere dayanan, aktif olanın öğretmen, pasif olanın ise öğrenci olduğu sadece okuma, anlatma şeklinde gerçekleştirilen öğretimin yerini öğrenci merkezli, öğrencileri araştırmaya sevk eden, buluş ve keşif yoluyla öğrenme gibi yenilikçi süreçler içeren bir yaklaşım almalıdır. Bu yönde bir çalışma alanı oluşturmak amacıyla Batı Estonya'nın Pärnu Bölgesi'nde; 'Environmental Education Centre (Çevresel Eğitim Merkezi)' adında bir bina inşa edilmiştir. Bu merkez 60 farklı kurs ve programıyla yenilikçi bir çevresel eğitim sunmaktadır (Henno, 2016).

Temel amacı çevre bilinci sağlayarak kalıcı davranış değişikliği oluşturmak olan çevre eğitiminin kazanım ve etkinliklerinde tekrardan uzaklaşılarak, eğlenceli, öğrenciyi sıkmayan, dikkat çekici, gündeme vurgu yapan, yazılı ve görsel medyadan yararlanan, teknolojiyi ön plana alan ve yenilikçi materyaller içeren bir yöntem izlenmesi sağlanmalıdır. Özellikle son dönemde ülkemizdeki eğitim süreçlerinde de yararlanılmaya başlanan eğitici çizgi romanlar bilişsel ve duyuşsal alana hitap eden etkili materyallerden biri olarak kabul edilmektedir. Sınıf içinde gerçekleştirilen eğitim söz konusu olduğunda içerik ve görsellik açısından zenginliğiyle, etki kapasitesi yüksek ve yaratıcı bir materyal sayılabilecek eğitici çizgi romanların akademik başarıyı arttırma, motivasyonu ve merak duygusunu tetikleme gibi özellikleriyle eğitimde son derece olumlu sonuçlar elde edilmesinde rol oynadığı bilinmektedir (Ghiso ve Low, 2013; İlhan, 2016; Topkaya, 2014; Topkaya, 2016; Topkaya ve Şimşek, 2015; Ünal, 2018). Yapılan araştırmalar sonucu eğitici çizgi romanlardan yararlanılarak gerçekleştirilen bir çevre eğitiminin öğrencilerin çevresel sorunları algılaması ve çevre ile ilgili konuları öğrenmesi üzerinde olumlu etkiler gösterdiği belirlenmiştir. Ayrıca söz konusu çevre eğitimini alan öğrencilerin akademik başarı (bilişsel) ve çevreye yönelik tutumlarında da (duyuşsal) önemli gelişmeler kaydedildiği belirtilmiştir (Topkaya, 2016; Topkaya ve Doğan, 2020). Yine yenilikçi öğretim materyallerinden bir örnek olarak son yıllarda Estonya'da gelişen çevre eğitimi kapsamında ilk Çevre Eğitimi (EE) etkileşimli web sitesi (www.keskkonnaharidus.ee, 2019), öğretmenlerin kullanımı için geliştirilmiştir. Web sitesi enerji verimliliği fırsatları, Estonya'daki çevre eğitim merkezleri ve öğretme-öğrenme materyalleri için geniş bilgi içermektedir. Ayrıca Estonya'da öğrenci ve öğretmenlere yönelik oluşturulan 'Çevresel Pusula' Estonya doğasının ormanları, sulak alanları, habitatlarına ait resim ve video galerileri içeren dijital bir ortam olup uygulama okul-doğa merkezi işbirliğini desteklemektedir (Henno, 2016; Kalıpçı, Öztaş ve Özdemir, 2010; Uzun ve Sağlam, 2007; Yılmaz, Morgil, Aktuğ ve Göbekli, 2002). 
- Çevre eğitimi diğer ders programları içine eklenerek ya da seçmeli ders kategorisinde arka planda verilerek değil bir bütün olarak ele alınmalı, eğitimin tüm kademelerinde ve tüm sınıf düzeylerinde 'Çevre Eğitimi' dersi adı altında zorunlu ders olarak okutulmalıdır. Bu konuda çeşitli ülkeler farklı stratejiler izlemektedir. Örneğin; Belçika, Finlandiya, Yunanistan gibi bazı Avrupa Birliği ülkelerinin öğretim programlarında çevre eğitimi diğer derslerden ayrı olarak tek başına bir ders olarak bulunurken, İspanya gibi bazı ülkelerin öğretim programlarında çevre eğitiminin tek bir yöntemle verilmesinin yeterli olmayacak kadar yoğun bir alan olduğu düşüncesiyle hem ayrı bir ders olarak hem de başka derslere entegre edilmiş olarak verilmesi uygun görülmektedir. Bu şekilde bir çevre eğitimi uygulamasının ülkemizdeki öğretim programlarında da yerini alması gerektiği araştırmacılar tarafindan da düşünülmektedir (Alım, 2006; Stokes, Edge ve West, 2001; Tanrıverdi, 2009).

- CÇağdaş yaklaşımlar göz önüne alınarak 'doğada sürdürülebilirlik 'bakış açısını temele alan yeni bir çevre eğitimi yaklaşımı benimsenmeli, benimsenen yaklaşım doğrultusunda çevre dersi içeriği ve kazanımları yeniden düzenlenmelidir (Muşlu Kaygısız, 2020). Bu çerçevede ekolojik ayak izi eğitimi önemsenmelidir (Kahyaoğlu ve Demirkol, 2019). Yine Endüstri 4.0 ve Endüstri 5.0 devrimlerinin çevre eğitimine yansımaları tartışılmalı ve bu kapsamda insanlığın geleceği açısından çevre dostu teknolojiler (yeşil enerji-yeşil teknoloji, topraksız tarım, organik tarım gibi), yapay zekâ uygulamaları, uzayda yaşam ortamı araştırmaları vb. konular çevre eğitimi kazanımları arasında yerini almalıdır. Ekolojik ayak izi eğitiminin yanı sıra karbon ayak izi eğitimine de önem verilmeli ve bireylerin karbon ayak izlerini azaltmaları için alması gereken önlemler anlatılmalıdır.

Çevre eğitiminde öğrencinin yaşayarak öğrenmesini, öğrendiklerini özümsemesini ve davranışa dökmesini sağlayacak teknikler öne çıkarılmalıdır. Bu amaçla; yerinde inceleme, doğa kampları, proje çalışmaları, gözlem, argümantasyon, öğrenme döngüsü, beyin firtınası, küme çalışması, görsel ve animasyon çalışmaları, rol yapma gibi aktif öğretim yöntem ve tekniklerine yer verilmesi gereklidir. İsveç, Norveç, İngiltere gibi bazı ülkelerde mekan dışı eğitimin sınıf içi eğitimle bütünleştirilerek uygulanan bir yöntem olduğu bilinmektedir. Bu yöntemin hem doğayı, hem o bölgenin coğrafi ve sosyo-kültürel özelliklerini, hem de doğa sporlarını içerdiği için tüm yaş dönemlerine hitap ettiği belirtilmektedir (Öztürk Aynal, 2013). Budak (2012) tarafından yapılan bir çalışmada doğada gerçekleştirilen geziler neticesinde öğrencilerin farkındalık, ilgi, duyarlılık ve merak düzeylerinde artış gözlenmiştir. $\mathrm{Bu}$ sonuç doğrultusunda doğada gerçekleştirilen etkinliklerin sayısı arttırılması öğrencinin çevresel farkındalık ve merak gibi alanlarında gelişme sağlayacağı düşünülmüştür. Doğal ortamlarda hareket eden öğrencinin duyularını daha fazla kullanması sonucunda problem çözüme yeteneklerinin arttığı, fiziken ve ruhen olumlu gelişim sağladığı bilinmektedir. Öğrencinin özgüvenin artması ve kendini rahat hissettiği doğal ortamlarda eğitim görmesi çevresel duyarlılığı ve farkındalığını artırtmaktadır (Budak, 2018). Amerika'da bulunan "Expeditionary Learning Schools (ELS)" okullarının prensiplerinden birinde, doğal dünya ile doğrudan gerçekleşen bir ilişkinin, insan ruhunu tazeleyeceği böylelikle tekrarlanan döngü ve etki-tepki ile ilgili önemli fikirler ortaya çıkarmalarını sağlayacağını belirtmektedir. Bu prensip ile öğrencilerin doğa ile uyumlu bir ilişki geliştirmelerini sağlamak amaçlanmaktadır. Amerika'da çevre eğitiminin bu tür okullarda büyük önem taşıdığı söylenebilir (Akınoğlu ve Sarı, 2009; Ravindranath, 2007). Ayrıca yine Amerika Birleşik Devletleri'nde gerçekleştirilen Öğrenme Ağı Projesi ve Yaban isimli çalışma gibi kapsamlı doğa eğitimleri öğrencinin çevresel duyarlılık, bilgi ve becerilerini \% 97'lik bir düzeyde farklılaştırdığı belirtilmiş̧tir (Budak, 2012; Council for Environmental Education, 2004a; 2004b; Pitman, 2004).

Çevre eğitimi kapsamında öğrencilerin aktif katılım gösterebileceği, ekip çalışması yapabileceği geniş ölçekli projeler oluşturulmalıdır. Ülkemizde çevre eğitimi kapsamında "Yeşil Kutu Çevre Eğitimi Projesi", "Eko-Okullar ve Okullarda Orman Projesi", "Çocukların Meyve Bahçesi”" gibi projeler uygulanmaktadır. Yeşil kutu projesi, MEB, Çevre Orman Bakanlığı, çeşitli üniversiteler ve akademisyenlerin işbirliği sonucu hazırlanmış bir projedir. TÜRÇEV tarafından yürütülen Eko-Okullar Projesi ise ilköğretim okullarına yönelik çevresel bilinç, çevre yönetimi ve 
sürdürülebilir kalkınma eğitimi verebilmek amacıyla uygulamaya koyulmuş olan bir programdır (Öztürk, 2013).

Çevre eğitimi, doğa temelli eğitimle birlikte düşünülmeli ve TÜBİTAK'ın desteklediği 4004-Doğa Eğitimi ve Bilim Okulları Destekleme Programı'ndan örgün eğitim öğrencileri ve öğretmenleri yanında, yetişkin çevre eğitimi çerçevesinde, daha geniş bir kitlenin yararlanması sağlanmalıdır.

- Çevre eğitimi açısından okulların mimarisinin insan-doğa ilişkisinin sürdürülebilirliğine uygun olarak şekillenmesi önemli bir husustur. Buna Vietnam'da Farming Kindergarden adı verilen doğaya dokunarak öğrenmeyi, sürdürülebilir yaşamı destekleyen ve pretzel (kıvrık) şeklinde inşa edilen anaokulu (https://gaiadergi.com/dogaya-dokunarak-ogrenencocuklar-vietnamin-surdurulebilir-anaokulu/, 2020) ve Almanya, İsveç, Danimarka'da yaygın olan orman anaokulları (Forest Kindergarden) örnek verilebilir (Kane ve Kane, 2011). Şehirler içerisinde yer alan öğretim kurumları için de Biyofilik Tasarım bir çözüm olarak önerilebilir (Beatley, 2011). Bir diğer husus ise özellikle üniversite kampüslerinin eko-kampüslere dönüştürülmesidir (Günerhan ve Günerhan, 2016).

Çocukların doğal çevreleri ile bağ kurmaları için doğal ve kentsel çevreyi bütünleştirecek düzenlemeler yapılmalıdır. İskandinav ülkelerinin şehir içerisinde doğaya en az müdahale ile yaptığı tasarımlar buna örnek olarak gösterilebilir (Paslı, 2019).

Çevre eğitiminde kültürel mirasın önemine dikkat çekilmelidir. Çünkü koruma bilincine sahip kişiler hem bugünü hem de geçmişi koruyabilir. Bu konuda yapılan çalışmalara örnek olarak Brüksel'de düzenlenen Eğitim ve Kültürel Miras Konferans1 örnek verilebilir. Bu konferans, eğitimin kültürel miras açısından önemine dikkat çekmek amacıyla yapılmıştır (Baysan, 2019).

- $\quad$ Gamble (2015)'in 'Sürdürülebilirlik İçin Eğitim Programı', ülkemizde farklı coğrafi bölgelerin özelliklerine uyarlanarak kullanılabilir. Bu program içeriğinde; yaşam tarzını kendini yenileyen bir hale getirme, sürdürülebilir enerji, sürdürülebilir bina, sürdürülebilir sahalardan yararlanma, kendi ürününü üretme, kış bahçesi, sürdürülebilir su kullanımı, eko-şehirler ve ulaşım alternatifleri, evde kullanılabilecek sürdürülebilir ürünler, yeşil ekonomi, sürdürülebilirliğin iç boyutları, sürdürülebilir bir dünya görüşü kazanmak gibi konular yer almaktadır (Duran ve Ekici, 2019).

- Doğal kaynakların sınırlı olmasına karşın insan ihtiyaçlarının sınırsızlı̆̆ çerçevesinde örgün ve yaygın eğitim kurumlarında "azaltılmış tüketimin" (Dobson, 2016) önemi üzerinde durulmalı ve su, elektrik tasarrufu yanında, yağmur hasadı vb. gibi yöntemlerle doğal kaynakların geri dönüşümü sağlanmalıdır. Örgün ve yaygın eğitim kurumlarındaki öğrencilere mezun olabilmeleri için yaşadıkları yerleşim biriminde orman bölge müdürlüklerinin belirlediği yangınlardan veya tahribattan zarar görmüş alanları ağaçlandırması (örneğin en az 10 ağaç) şartı getirilebilir. Filipinler'de 2019'da yürürlüğü giren yasa, bu uygulamaya örnek olarak gösterilebilir (Cockburn, 2019).

- $\quad$ Çevre eğitimi, erken yaşta başlayarak hayat boyu (sadece Z kuşağının eğitimi yeterli değildir) sürdürülmeli, bireylerde bilgi edinmenin yanı sıra olumlu tutum ve davranış oluşturmalıdır. Çevre eğitimi sadece bir ders olarak görülmeyip her yaştan insana çevre bilinci kazandirılmalıdır.

- $\quad$ Çevre eğitiminde kısmen her disiplinden yararlanılmalı ve bu kısımlar dengeli bir biçimde bütünleştirilerek disiplinler arası bir yaklaşım izlenmelidir. Tiflis Konferansı'nda da çevre eğitiminde, bütüncül ve dengeli olacak şekilde disiplinler arası bir yaklaşım benimsenmesi gerektiği bildirilmiştir. Danimarka gibi birçok ülkede çevre eğitiminin disiplinler arası bir anlayışla verildiği bilinmektedir (Güven ve Hamalosmanoğlu, 2012; Intergovernmental Conference on Environmental Education-Final Report, 1978; Stokes, Edge ve West, 2001; Tanrıverdi, 2009).

- $\quad$ Öğrencilere problem çözme, eleştirel düşünme, çevresel okuryazarlık gibi beceriler her yaş grubuna uygun olacak biçimde verilmeye çalışılmalıdır. 
- $\quad$ Öğrencilerin çevre hakkında konferans ve seminerlere katılması, düzenli olarak konuya ilişkin belgesel ya da film izlemeleri, çevre hakkında çalışmalar yapan sivil toplum kuruluşlarında aktif rol almaları için programlarda bunları zorunlu kılan bazı düzenlemeler yapılmalidır.

Çevre duyarsızlığının temelinde ahlaki sorunlar yatmaktadır. Buna bağlı olarak çevresel değerlerin benimsetilmesi amacıyla bireylerin ahlaki olgunlaşmalarını sağlayacak etkinliklere yer verilmelidir. Bunun yanında disiplinler arası akademik çalışmalar 1şı̆ı̆ında çevre eğitimine de yön verebilecek Türkiye'ye özgün ve evrensel içeriğe sahip bir çevre etiği yaklaşımı geliştirilmelidir.

- $\quad$ Çevresel sorunların genellikle küçük çapta değil küresel boyutlarda etkili olması nedeniyle öğrencilere sadece yakın çevreleri değil tüm dünya genelindeki çevre sorunları anlatılmalı, geniş ölçekli düşünme yeteneği edinmeleri sağlanmalıdır.

- $\quad$ Bir konuda yeterliliğe sahip olmayan kişinin bu konuyu bir başkasına öğretmesi mümkün değildir. Bu amaç doğrultusunda okul öncesi dönem de dahil olmak kaydıyla tüm öğretim kademelerinde çevre eğitimi dersini anlatacak olan öğretmenlere yönelik hizmet içi eğitimler ve seminerler düzenlenmelidir. Mevcut öğretmenlerin sürekli olarak bu alanda gerçekleştirilen akademik çalışmaları takip etmeleri sağlanmalı, mümkünse öğretmenlerin kendi alanlarında yüksek lisans eğitimi almaları teşvik edilmelidir. Öğretmen olmak için lisans mezuniyeti şartının yetersizliği artık dünyada oldukça yaygın bir uygulama haline gelmiş durumdadır. Estonya, Almanya, Fransa, Finlandiya, İtalya gibi bazı OECD ülkelerinde ortaokul ve lise seviyesinde öğretmenlik yapacak kişilerin en az yüksek lisans derecesine sahip olmaları gerekmektedir (Organisation for Economic Co-operation and Development, 2014).

Ülkemizde çevre eğitiminin durumu, geleceği ve geliştirilmesine yönelik çalışma sayısı oldukça sınırlıdır. Bu konudaki akademik çalışmalar arttırılarak konuya farklı bakış açıları getirilmelidir.

\section{Kaynakça}

Akınoğlu, O. \& Sarı, A. (2009). İlköğretim programlarında çevre eğitimi. Atatürk Eğitim Fakültesi Eğitim Bilimleri Dergisi, 30, 5-29.

Aktepe, V. \& Temur, M. (2018). Öğretim Programlarında Çevre Eğitimi. R. Sever ve E. Yalçınkaya (Ed.) Çevre Eğitimi içinde (s.131-135). Pegem Akademi Yayıncılık.

Alagöz, B. (2010). Çevre eğitimine farklı bir yaklaşım: sosyal-ekolojik sistemler. e-Journal of New World Sciences Academy. 5(4), 75-86.

Alım, M. (2006). Avrupa Birliği üyelik sürecinde Türkiye'de çevre ve ilköğretimde çevre eğitimi. Kastamonu Ĕ̈itim Dergisi, 14(2), 599-616.

Alkış, S (2002). İlköğretimde tarihi çevre eğitimi [Yayınlanmamış yüksek lisans tezi]. Uludă̆ Üniversitesi Sosyal Bilimler Enstitüsü İlköğretim Anabilim Dalı.

Atasoy, E. (2005). Çevre içi eğitim: ilkögrretim öğrencilerinin çevresel tutum ve çevre bilgisi üzerine bir çalışma. [Yayınlanmamış Doktora Tezi]. Uludağ Üniversitesi Sosyal Bilimler Enstitüsü Ilköğretim Anabilim Dalı.

Atasoy, E. (2006). Çevre için eğitim çocuk doğa etkileşimi. Ezgi Kitabevi.

Başaran, İ. E. (1977). Eğitime Giriş (2. Baskı). Bilim Matbaası.

Baysan, S. (2019). Sosyal Sorumluluk Çalışmaları ve Kültürel Mirasın Sürdürülebilirliği, N. Özgen ve M. Kahyaoğlu (Ed.) Sürdürülebilir Kalkınma içinde (s.256-300). Pegem Akademi Yayınları. 
Beatley, T. (2011). Biophilic cities: integrating nature into urban design and planning. Washington, D.C., USA: Island Press.

Benzer, E. (2010). Proje tabanlı ögrenme yaklaşımıyla hazırlanan çevre eğitimi dersinin fen bilgisi ögretmen adaylarının çevre okuryazarlığına etkisi. [Yayınlanmamış Doktora Tezi]. Marmara Üniversitesi Eğitim Bilimleri Enstitüsü İlköğretim Ana Bilim Dalı Fen Bilgisi Öğretmenliği Bilim Dal1.

Bildik, G. (2011). Illkögretim 7. sınıfta verilen çevre konusunun ögrencilerin çevresel tutumu ve çevre bilgisi üzerine etkisi. [Yayınlanmamış Yüksek Lisans Tezi]. Gazi Üniversitesi Eğitim Bilimleri Enstitüsü Fen Bilgisi Öğretmenliği Bilim Dalı.

Bilgi, M. G. (2008). Ortaöğretim kurumlarında coğrafya dersi kapsamındaki çevre konularının ögretiminde aktif ögrretim yöntemlerinin rolü [Yayınlanmamış Doktora Tezi]. Gazi Üniversitesi Eğitim Bilimleri Enstitüsü Coğrafya Öğretmenliği Bilim Dalı.

Birinci, O. (2013). İlkokul 3. sinıf Hayat Bilgisi dersine yönelik gelişstirilen doğa eğitimi etkinliklerinin öğrencilerin doğa algılarına etkisi. [Yayınlanmamış Yüksek Lisans Tezi]. Recep Tayyip Erdoğan Üniversitesi Sosyal Bilimler Enstitüsü Sınıf Öğretmenliği Anabilim Dali.

Budak, F. M. (2012). Sosyal Bilgiler dersinde (7.sınıf) doğal ve kültürel varlıklar aracıll̆ğ ile estetik değerler eğitimi (Tokat örneği). [Yayınlanmamış Doktora Tezi]. Atatürk Üniversitesi Eğitim Bilimleri Enstitüsü İlköğretim Anabilim Dalı.

Budak, M. (2018). Doğa temelli çevre eğitimi, R. Sever \& E. Yalçınkaya (Ed.), Çevre Eğitimi içinde (s.293-307). Pegem Akademi Yayıncılık.

Bullock, J. R. (1994). Helping Children Value and Appreciate Nature. Day Care and Early Education, 21 (4), 4-8.

Bulut, M. (2015). Ortaöğretim ögrencilerinin çevresel risk algısı, tutum ve bilgi düzeylerinin belirlenmesi üzerine bir çalışma. [Yayınlanmamış Yüksek Lisans Tezi]. Niğde Üniversitesi Sosyal Bilimler Enstitüsü Kamu Yönetimi Ana Bilim Dalı.

Chawla, L. (1992). Research priorities in enviromental education. Children's Enviroment, 68-71.

Cockburn, H. (2019). Filipinler'de en az 10 fidan dikmeyen öğrenci mezun olamayacak, https://www.independentturkish.com/node/36501

Council for Environmental Education [CEE]. (2004a). Project Wild Aquatic K-12 Curriculum\&Activity Guide. U.S.A.

Council for Environmental Education [CEE]. (2004b). Project Wild K-12 Curriculum\&Activity Guide. U.S.A.

Çelik M. A. \& Gülersoy, A. E. (2016). Kaos ortamında (çağında) mekân-insan etkileşimine bütüncül bir bakış: Ekolojik toplum paradigması. FLSF (Felsefe ve Sosyal Bilimler Dergisi), 22, 163-183.

Çelikbaş, A. (2016). Sürdürülebilirliği temel alan çevre eğitiminin ortaokul öğrencilerinin çevresel davranışlarına ve sürdürülebilir çevre tutumlarına etkisi. [Yayınlanmamış Yüksek Lisans Tezi]. Mersin Üniversitesi Eğitim Bilimleri Enstitüsü Fen Bilgisi Eğitimi Bilim Dalı.

Çetin, O. (2018). Çevre Eğitimi Yaklaşımları. R. Sever ve E. Yalçınkaya (Ed.) Çevre Eğitimi içinde (s. 164-193). Pegem Akademi Yayıncılık.

Çevre Bakanlığı [ÇB]. (1998). Çevre Notları. Ankara: Çevre Eğitimi ve Yayın Dairesi Başkanlığı. 
Çolakoğlu, E. (2010). Haklar söyleminde çevre eğitiminin yeri ve Türkiye'de çevre eğitiminin anayasal dayanaklar1. Türkiye Barolar Birlĭgi Dergisi, 23:(88), 151-171.

Demir, E. \& Yalçın, H. (2014). Türkiye'de çevre eğitimi. Türk Bilimsel Derlemeler Dergisi, 7 (2), $07-18$.

Demir, Z. (2019). Çevre eğitiminde argümantasyon uygulamalart ile zenginleştirilmiş $5 E$ öğrenme metodunun 7.sınıf ögrencilerinin akademik başarılarına, eleştirel düşünme ve tartışma becerilerine etkisi. [Yayınlanmamış Yüksek Lisans Tezi]. Sivas Cumhuriyet Üniversitesi Eğitim Bilimleri Enstitüsü İlköğretim Anabilim Dalı Fen Bilgisi Eğitimi Bilim Dalı.

Devlet Planlama Teşkilatı [DPT]. (1994). Çevre eğitimi, insan gücü ve katılım planlaması, VII. beş yıllık kalkınma planı özel ihtisas komisyonu. Devlet Planlama Teşkilatı.

Dikicigil, Ö. \& Gülersoy, A.E. (2020). Social studies pre-service teachers' awareness of environmental ethics, Ilkogretim Online - Elementary Education Online, 2020; 19 (3), 1579-1591. http://dx.doi.org/ 10.17051/ilkonline.2020.734482

Dinçer, M. (1988). Çevre bilinci oluşturulmasında çevre eğitiminin rolü. [Yayınlanmamış Yüksek Lisans Tezi]. Hacettepe Üniversitesi Sosyal Bilimler Enstitüsü Sosyoloji Anabilim Dalı.

Dobson, A. (2016). Ekolojizm. Yeni İnsan Yayınevi.

Doğan, M. (1998). Stockholm konferansından günümüze Türkiye'de çevre eğitimi. Çevre ve İnsan, 40, 28-33.

Duran, V. \& Ekici G. (2019). Sürdürülebilir Çevre, N. Özgen ve M. Kahyaoğlu (Ed.) Sürdürülebilir Kalkınma içinde (s. 256-300). Pegem Akademi Yayınları.

Dülger, İ. (2018). Toxic effects of neonicotinoid insecticides on non-target organisms. $M C B \ddot{U}$ Sosyal Bilimler Dergisi, 16, Say1:1/2, 187-196. 10.18026/cbayarsos.424090

Elder, J. L. (2003). A field guid to environmental literacy: Making strategic investments in environmental education. Rock Spring: Environmental Education Coalition.

Erdoğan, M., Bahar, M., \& Uşak, M. (2012). 2007 yılında uygulanmaya başlanan lise 9-12. sınıf biyoloji dersi öğretim programlarında çevre eğitimi. Kuram ve Uygulamada Eğitim Bilimleri/ Educational Sciences: Theory \& Practice,12(3), 2217-2235.

Ergün, T. \& Çobanoğlu, N. (2012). Sürdürülebilir kalkınma ve çevre etiği. Ankara Üniversitesi Sosyal Bilimler Enstitüsü Dergisi, 3(1), 97-123. http://dx.doi.org/ 10.1501/sbeder_0000000041

Erol, G. H. (2005). Sinıf öğretmenliği ikinci sınıf ögrencilerinin çevre ve çevre sorunlarına yönelik tutumları. [Yayınlanmamış yüksek lisans tezi]. Pamukkale Üniversitesi Fen Bilimleri Enstitüsü İlköğretim Anabilim Dalı.

Erten, S. (2003). 5. sınıf öğrencilerinde "çöplerin azaltılması" bilincinin kazandırılmasına yönelik bir öğretim modeli. Hacettepe Üniversitesi Eğitim Fakültesi Dergisi, 25:94-103.

Erten, S. (2004). Çevre eğitimi ve çevre bilinci nedir, çevre eğitimi nasıl olmalıdır. Çevre ve İnsan Dergisi, Çevre ve Orman Bakanlığı Yayın Organı. Sayı 6566. 200625.

Ertürk, R. (2017). İlkokul öğrencilerinin çevre sorunları ve çevre eğitimine yönelik algıları. İnönü University Journal of the Faculty of Education, 18(3), 12-24.

Ertürk, S. (1979). Eğitimde program geliştirme. Ankara.

Gamble, L. A. (2015). Fundamentals of sustainable living. The Teaching Company. 
Ghiso, M. P. \& Low, D. E. (2013). Students using multimodal literacies to surface micronarratives of United States immigration. Literacy, 47(1), 26-34.

Görümlü, T. (2003). Liselerde çevreye karşı duyarlılı̆̆ın oluşturulmasında çevre eğitiminin önemi. [Yayınlanmamış Yüksek Lisans Tezi]. Gazi Üniversitesi, Eğitim Bilimleri Enstitüsü.

Gräsel, C. (2002). “Umweltbildung”, HandbuchBildungsforschung. Opladen, 675-689.

Gronemeyer, M. (1987). Ecological education a failing practice? or is the ecological movement an educational movement?", in Adult Education and the Challenges of the 1990s. WalterLeirman\&LindraKulich (Ed.), p. 70-83, New York: CroomHelm.

Gülay, H. \& Önder, A. (2011). Sürdürülebilir gelişim için okulöncesi dönemde çevre eğitimi. Nobel Yayın Dağıtım.

Gülersoy, A. E. (2014). Yanlış arazi kullanımı. Elektronik Sosyal Bilgiler Eğitimi Dergisi, C/S. 1 (2): 49-128.

Gülersoy, A. E. (2019a). İnsan-doğa ilişkiselliğinde sürdürülebilirliğin yeniden düşünülmesi, Nurettin Özgen, Mustafa Kahyaoğlu (Ed.), Sürdürülebilir kalkınma içinde (301-338), Pegem Akademi Yayınları.

Gülersoy, A.E. (2019b). Mekân-insan etkileşiminin ıslahına bâtıni bir yorum: Rıza şehri (kâmil toplum). Barbaros Gönençgil (Ed.), 1. İstanbul Uluslararası Coğrafya Kongresi Bildiri Kitabl 20-22 Haziran 2020 içinde (ss. 85-94), İstanbul Üniversitesi. https://doi.org/10.26650/PB/PS12.2019.002.009

Gümüş, N., Gülersoy, A. E. \& Avcı, G. (2017). Arazi kullanım bilincinin üniversite öğrencileri açısından değerlendirilmesi. JASS The Journal of Academic Social Science Studies, 56, 351368. http://dx.doi.org/10.9761/JASSS7006

Günerhan, S. \& Günerhan, H. (2016). Türkiye için sürdürülebilir üniversite modeli. Mühendis ve Makina, 57 (682), 54-62.

Güven, E. \& Hamalosmanoğlu, M. (2012). İlköğretim 4. Sınıf Fen ve Teknoloji ders kitabındaki çevre içerikli etkinliklerin disiplinler arası yaklaşım yönünden incelenmesi. Journal of European Education, 2(1).

Güven, E. (2012). Disiplinler arası yaklaşıma dayalı çevre eğitiminin ilköğretim 4. Sinıf ögrencilerinin çevreye yönelik tutumlarına ve davranışlarına etkisinin incelenmesi. [Yayınlanmamış Yüksek Lisans Tezi]. Erciyes Üniversitesi, Eğitim Bilimleri Enstitüsü.

Hansen, S. (2004). A constructivist approach to project assessment. European Journal of Engineering Education, 29(2), 211-220.

Henno, I. (2016). Ten years of education for sustainable development in Estonia. Chief Expert of Ministry of Education and Research of Estonia.

https://gaiadergi.com/dogaya-dokunarak-ogrenen-cocuklar-vietnamin-surdurulebilir-anaokulu/. (2020), Erişim Tarihi: 30.05.2020.

Hungerford, H.R., \& Peyton, R.B. (1994). Procedures for Developing an Environmental Education Curriculum (Revised): A Discussion Guide for UNESCO Traning Seminars on Environmental Education, UNESCO-UNEP International Environmental Education $\begin{array}{llll}\text { Programme, } & \text { Environmental } & \text { Education }\end{array}$ http://unesdoc.unesco.org/images/0013/0013454eo.pdf. Erişim Tarihi: 05.03.2018.

Ilgar, R. (2007). Çevre eğitiminde yaygın eğitimin rolü ve önemi. On Dokuz Mayıs Üniversitesi Eğitim Fakültesi Dergisi. 23, 38-50. 
Intergovernmental Conference on Environmental Education-Final Report. (1978). UnescoUNEP, Tbilisi (USSR), 14-26 October 1977.

İleri, R. (1998). Çevre eğitimi ve katılımın sağlanması. Ekoloji Çevre Dergisi, 28, 3-9.

İlhan, A., Gülersoy, A. E. \& Gülersoy, V. K. (2017). Kuantum öğrenme yaklaşımı ve coğrafya ögretimi. International Periodical for the Languages, Literature and History of Turkish or Turkic, Volume 12/14, 187-210.

İlhan, G. O. (2016). Sosyal bilgiler öğretiminde çizgi romanların kullanımı. [Unpublished Doctoral Dissertation]. Afyon Kocatepe University Graduate Institute of Social Sciences.

Kabaş, D. (2004). Kadınların çevre sorunlarına ilişkin bilgi düzeyleri ve çevre eğitimi. [Yayınlanmamış Yüksek Lisans Tezi]. Gazi Üniversitesi, Eğitim Bilimleri Enstitüsü (No:191805).

Kahn, R. (2010). Critical pedagogy, ecoliteracy, \& planetarycrisis. New York: Peter Lang Publishing.

Kahyaoğlu, M. \& Demirkol, M. (2019). Ekolojik Ayak İzimiz, Nurettin Özgen, Mustafa Kahyaoğlu (Editör), Sürdürülebilir Kalkınma içinde (38-52), Pegem Akademi Yayınları.

Kalıpçı, E., Öztaş, H. \& Özdemir, C. (2010). Çevre mühendisliği öğrencilerinin çevre ile ilgili bilgilerini günlük yaşama uygulayabilme düzeyleri. Karadeniz Uluslararası Bilimsel Dergi, 5, 41-53.

Kane B. A. \& Kane J. (2011). Waldkindergarten in Germany. Green Teach., 94, 16-19.

Kaskens, A., Meijberg, W., Stokking, K. \& Van, L. (1999). Evaluating Environmental Education. Cambridge, UK: IUCN.

Kesercioğlu, G. (2010). Yetişkin çevre eğitimi ile çevre mühendisleri arasındaki ilişskinin incelenmesi. [Yayınlanmamış Yüksek Lisans Tezi]. Ankara Üniversitesi, Sosyal Bilimler Enstitüsü.

Kızıl, M. (2012). Çevre Bilimi dersinin fen bilgisi ögretmen adaylarının çevre bilgisi ve çevreye karşı tutumlarına olan etkisinin incelenmesi. [Yayınlanmamış Yüksek Lisans Tezi]. Niğde Üniversitesi Eğitim Bilimleri Enstitüsü.

Kiziroğlu, İ. (2000). Türk eğitim sisteminde çevre eğitimi ve karşılaşılan sorunlar, Uluslararası Ekoloji ve Çevre Sorunları Sempozyumu, 157-164.

Klautke, S. \& Köhler, K. (1991). Umwelterziehung- ein didaktisches Konzept, Zeitschrift: Unterricht Biologie (UB) 164(15) 48-51.

Korkmaz, H. (2004). Fen ve teknoloji eğitiminde alternatif değerlendirme yaklaşımları. Yeryüzü Yayınevi, 79-92.

Korkmaz, H., \& Kaptan, F. (2001). Fen eğitiminde proje tabanlı öğrenme yaklaşımı. Hacettepe Üniversitesi Ĕ̈itim Fakültesi Dergisi, 20, 193-200.

Krasny, M. E. \& Tidball, K. G. (2008). Application of resilience theory to education for sustainable development. A paper presented at the Stockholm Resilience Conference.

Krasny, M. E. \& Tidball, K. G. (2009). Applying a resilience systems frame work to urban environmental education. Environmental Education Research, 15(4), 465-482.

Küçük, N. (2017). Ortaokullarda uygulamalı çevre eğitiminin çevre bilinci üzerine etkisi (Balıkesir örneği). [Yayınlanmamış Yüksek Lisans Tezi]. Balıkesir Üniversitesi, Sosyal Bilimler Enstitüsü. 
Kyburz-Graber, R., Rigendinger, L., Hirsch, G., \& Werner, K. (1997). A socio-ecological approach to interdisciplinary environmental education in senior high schools. Environmental Education Research, 3(1), 17-28.

Louv, R. (2008). Doğadaki Son Çocuk. (Çeviren: Temürcü, C.), TÜBİTAK.

Mamur, N. (2017). Ekolojik sanat: çevre eğitimi ile sanatın kesişme noktası. Mersin Üniversitesi Eğitim Fakültesi Dergisi, 13(3), 1000-1016. https://doi.org/10.17860/mersinefd.304070

Mansoor, I., \& Moss, D. (1997). Project based learning and assessment: A resourcemanual for teachers. (ERIC Document Reproduction Service No.ED442306).

Mert, M. (2006). Lise öğrencilerinin çevre eğitimi ve katı atıklar konusundaki bilinç düzeylerinin saptanması. [Yayınlanmamış Yüksek Lisans Tezi]. Hacettepe Üniversitesi, Orta Öğretim Fen ve Matematik Alanlar Bölümü, Biyoloji Eğitimi Anabilim Dalı.

Mesleki ve Teknik Eğitim Öğretim Programları [MEGEP]. (2019). Mesleki ve Teknik Eğitim Öğretim Programlarl $\quad(9,10,11,12$ Sinflar $)$. http://www.megep.meb.gov.tr/?page=ogretimProgramlari Erişim tarihi: 25.05.2020

Milli Eğitim Bakanlığı [MEB]. (2018). Sosyal Bilgiler Dersi Öğretim Programı (İlkokul ve Ortaokul 3,4,5,6,7. Siniflar). Talim ve Terbiye Kurulu Başkanlığı, Ankara. https://ttkb.meb.gov.tr/www/ogretim-programlari/icerik/72 Erişim tarihi: 05.05.2020

Milli Eğitim Bakanlığı [MEB]. (2015). Çevre Ĕ̆itimi Dersi Öğretim Programı (Ortaokul 7,8. Sinıflar). Talim ve Terbiye Kurulu Başkanlı̆̆ https://ttkb.meb.gov.tr/www/ogretim-programlari/icerik/72 Erişim tarihi: 27.05.2020

Milli Eğitim Bakanlığı [MEB]. (2017). Şehrimiz... Dersi Öğretim Programı (Ortaokul 5,6,7 ve 8. Sinıflar). Talim ve Terbiye Kurulu Başkanlığı, Ankara. https://ttkb.meb.gov.tr/www/ogretim-programlari/icerik/72 Erişim tarihi: 27.05.2020

Milli Eğitim Bakanlığı [MEB]. (2018). Biyoloji Dersi Öğretim Programı (Ortaokul 9,10,11,12. Sinıflar). Talim ve Terbiye Kurulu Başkanlığı, Ankara. https://ttkb.meb.gov.tr/www/ogretim-programlari/icerik/72 Erişim tarihi: 05.05.2020

Milli Eğitim Bakanlığı [MEB]. (2018). Coğrafya Dersi Öğretim Programı (Ortaokul 9,10,11,12. Sinıflar). Talim ve Terbiye Kurulu Başkanlığı, Ankara. https://ttkb.meb.gov.tr/www/ogretim-programlari/icerik/72 Erişim tarihi: 05.05.2020

Milli Eğitim Bakanlığı [MEB]. (2018). Fen Bilimleri Dersi Öğretim Programı (İlkokul ve Ortaokul 3,4,5,6,7,8. Siniflar). Talim ve Terbiye Kurulu Başkanlığı, Ankara. https://ttkb.meb.gov.tr/www/ogretim-programlari/icerik/72 Erişim tarihi: 05.05.2020

Milli Eğitim Bakanlığı [MEB]. (2018). Hayat Bilgisi Dersi Öğretim Programı (İlkokul 1,2 ve 3. Sinıflar). Talim ve Terbiye Kurulu Başkanlığı, Ankara. https://ttkb.meb.gov.tr/www/ogretim-programlari/icerik/72 Erişim tarihi: 05.05.2020

Milli Eğitim Bakanlığı [MEB]. (2018). Kimya Dersi Öğretim Programı (Ortaokul 9,10,11,12. Sinıflar). Talim ve Terbiye Kurulu Başkanlığı, Ankara. https://ttkb.meb.gov.tr/www/ogretim-programlari/icerik/72 Erişim tarihi: 20.05.2020

Milli Eğitim Bakanlığı. [MEB]. (2018). Să̆lık Bilgisi ve Trafik Kültürü Dersi Öğretim Programı (Ortaokul 9. Sinıf). Talim ve Terbiye Kurulu Başkanlığı, Ankara. https://ttkb.meb.gov.tr/www/ogretim-programlari/icerik/72 Erişim tarihi: 20.05.2020

Mucunguzi, P. (1995). Environmental education in the formal sector education in Uganda. Environmental Education Research, 1 (2). 
Muşlu Kaygısız, G. (2020). Fen bilimleri dersi öğretim programı ve okul öncesi eğitim programındaki kazanımların çevre eğitimi açısından incelenmesi. International Journal of Early Childhood Education Studies, 5 (1), 29-47.

Nazlığlu, M. (1991). Çevre eğitiminin önemi. Çevre üzerine, Türkiye Çevre Sorunları Vakfı Yayını, Önder Matbaası. 249-265.

Okur Berberoğlu, E. \& Uygun, S. (2013). Tübitak 4004 projelerinin sürdürülebilir kalkınma için çevre eğitimi kapsamında değerlendirilmesi. Abant İzzet Baysal Üniversitesi Eğitim Fakültesi Dergisi, 13(2), 107-133.

Okur Berberoğlu, E. (2015). Ekopedagoji temelli sınıf dışı çevre eğitiminin çevre farkındalığı üzerinde etkisi. Hasan Ali Yücel Eğitim Fakültesi Dergisi, 12(1), 67-81.

Okur, E. (2012). Sinıf dışı deneyimsel öğretim: Ekoloji uygulaması. [Yayınlanmamış DoktoraTezi]. Onsekiz Mart Üniversitesi Eğitim Bilimleri Enstitüsü Eğitim Bilimleri Bilim Dalı.

Onions, C., T. (Ed.). (1964). The shorter oxford english dictionary. Oxford: Clarendon Press.

Organisation for Economic Co-operation and Development [OECD]. (2014). Education at a glance 2014: OECD indicators.

Ozaner, S. (2004). "Çevre (doğa ĕgitimi)”. çevre sorunlarına çağdaş yaklaşımlar - ekolojik, ekonomik, politik ve yönetsel perspektifler- Betaş Yay. 1. Bask1.

Özbuğutlu, E., Karahan, S., \& Tan, Ç. (2014). Çevre eğitimi ve alternatif yöntemler. Mustafa Kemal Üniversitesi Sosyal Bilimler Enstitüsü Dergisi, 11:(25), 393-408.

Özdemir, O. \& Uzun, N. (2006). Yeşil sınıf modeline göre yürütülen fen ve doğa etkinliklerinin anasınıfı öğrencilerinin çevre algılarına etkisi. Çocuk Gelişimi ve Eğitimi Dergisi, 3(1), 12 20.

Özdemir, O. (1998). Yazınsal bir tür olarak öykünün çevre duyarlığına etkisi. [Yayınlanmamış yüksek lisans tezi]. Ankara Üniversitesi Sosyal Bilimler Enstitüsü.

Özdemir, O. (2007). Yeni bir çevre eğitimi perspektifi 'sürdürülebilir gelişme amaçlı eğitim”'. Eğitim ve Bilim Dergisi, 145, 23-39.

Özdemir, O. (2010). Doğa deneyimine dayalı çevre eğitiminin ilköğretim öğrencilerinin çevrelerine yönelik alg1 ve davranışlarına etkisi. Pamukkale Üniversitesi Eğitim Fakültesi Dergisi, 27, 125-138.

Özdemir, O., Özkan Y., \& Özgen Ö. (2006). Research On Education Edited by Marina-Stefania Giannakaki, Gregory T. Papanikos, Yiannis Pozios\& John Kelvyn Richards. Biotechnological Foods-Sustainable Development: Sustainable Consumtion Education.

Özgel, Z. T., Aydoğdu, M. \& Güven Yıldırım, E. (2018). Doğa kampı destekli çevre eğitiminin çevre sorunlarına yönelik farkındalık ve tutuma etkisi. Ihlara Ĕgitim Araştırmaları Dergisi, 3(2), 90-106.

Özoğlu, S. Ç. (1993). Yaygın eğitim düzeyinde çevre için eğitim. Çevre eğitimi. Türkiye Çevre Vakfi Yayınları, 65-80.

Öztürk Aynal, Ş. (2013). Haydi çocuklar doğaya ve bahçelere açılıyoruz: mekân dışı eğitim İsveç’ten örnekler. International Journal of Social Science, 6(1), 371-384. http://dx.doi.org/10.9761/JASSS_492

Öztürk, E. (2013). Uluslararası bir çevre eğitimi projesinin fen ve teknoloji ögretmen adaylarının çevre bilincine etkisi. [Yayınlanmamış Doktora Tezi], Hacettepe Üniversitesi Eğitim Bilimleri Enstitüsü İlköğretim Anabilim Dalı. 
Öztürk, M. (2017). Süründürülebilir gelişme odaklı eğitim: kuramsal çerçeve, tarihsel gelişim ve uygulamaya dönük öneriler. Illkögretim Online, 16(4),1-11. http://dx.doi.org/: 10.17051/ilkonline.2017.342997

Öztürk, S. (1990). Tarım ilaçları, Hasad Yayıncılık.

Pasl1, A. M. (2019). Doğal çevre, kent ve çocuk ilişkisini yeniden kurmak "İskandivanya'da doğa temelli eğitim ve İsveç Orman Okulu örneği" [Yayınlanmamış Yüksek Lisans Tezi]. İstanbul Şehir Üniversitesi Sosyal Bilimler Enstitüsü, Şehir Çalışmaları Anabilim Dalı.

Phenice, L. A. \& Griffore, R. J. (2003). Young children and the natural world. Contemporary Issues in Early Childhood, 4(2), 167-171. https://doi.org/10.2304/ciec.2003.4.2.6

Pitman, B. J. (2004). Project WILD: a summary of research findings 1983--1985 and 1996-2003. Houston, TX : Council for Environmental Education.

Prince, M., \& Felder, R. (2007). The many faces of inductive teaching and learning. Journal of College Science Teaching, 36(5), 14-20.

Pruneau, D. , Freiman, V., Barbier, P.V. , \& Langis, J. (2009). Helping young students to better pose an environmental problem. Applied Environmental Education and Communication, 8,105-113. https://doi.org/10.1080/15330150903133678.

Ravindranath, M. J. (2007). Environmental educaton in teacher education in India: Experiences and challenges in the United Nation's decade of education for sustainable development. Journal of Education for Teaching, 33(2), 191-206.

Rickinson, M. (2001). Learners and learning in environmental education: a critical review of the evidencell. Environmental Education Research, 7 (3), 207- 319.

Roth, C. E. (1992). Environmental literacy: 1ts roots, evolution and directions in the 1990s. Columbus, OH: ERIC Clearing house for Science, Mathematics, and Environmental Education.

Sauve, L. (2005). Una cartografía de corrientes en educación ambiental [A map of currents in environmental education]. In M. Sato \& I. Carvalho (Eds.), A Pesquisa em Educação Ambiental: Cartografias de uma Identidade Narrativa em Formação. Porto Alegre: Artmed.

Saylan, N. \& Karamete, A. (1999). Orta öğretim fen ve matematik öğretmen eğitimi; alan bilgisi programının değerlendirilmesi. Dokuz Eylül Üniversitesi Buca Eğitim Fakültesi Dergisi Yayınları,10, 181-191.

Schleicher, K. (1989). Beyond environmental education: The need for ecological awareness. International Review of Education, 35(3), 257- 281.

Senemoğlu, N. (1997). Gelişim öğrenme ve ögretim kuramdan uygulamaya. Ertem Matbaac1lık.

Sert Çıbık, A. (2019). Öğretim programlarında çevre eğitimi, H. G. Hastürk (Ed.). Çevre eğitimi içinde (s. 277-344). Anı Yayınc1lı.

Stokes, E., Edge, A. \& West, A. (2001). Environmental education in the educational systems of the european union final report. Centre for Educational Research London School of Economics And Political Science.

Strateji ve Bütçe Başkanlığı (SBB). (2014). Onuncu Kalkınma Planı: 2014-2018, T. C. Cumhurbaşkanlığı Strateji ve Bütçe Başkanlığı Yayını. Erişim adresi: http://www.sbb.gov.tr/wp-content/uploads/2018/11/Onuncu-Kalk\%C4\%B1nma-

Plan\%C4\%B1-2014-2018.pdf 
Strateji ve Bütçe Başkanlığı (SBB). (2019). Onbirinci Kalkınma Planı: 2019-2023, T. C. Cumhurbaşkanlığı Strateji ve Bütçe Başkanlığı Yayını. Erişim adresi: http://www.sbb.gov.tr/wp-content/uploads/2019/07/On birinci Kalkinma Plani.pdf

Şahin, F. (2004). Proje ile öğretim aşamaları. T.C. Maltepe Üniversitesi, Illk ve orta öğretimde araştırma teknikleri ve proje. Maltepe Üniversitesi, 24-29.

Tanrıverdi, B. \& Kablan, Z. (2008). Sustainable environmental education in primary school curriculum: perspectives from finland, rreland and Turkey. WCCI 13th World Conference in Education on "Creating a Global Culture of Peace: Strategies for Curriculum Development and Implementation". 2-7 September. Antalya, Turkey. Vol. II. pp.623-644 (Eds. Mirici, İ. H., Aksu Ataç, B., Arslan, M.M., Kovalcikova, I.).

Tanrıverdi, B. (2009). Sürdürülebilir çevre eğitimi açısından ilköğretim programlarının değerlendirilmesi. Ĕgitim ve Bilim, 34 (151), 89-103.

Tay, B. \& Baş, M. (2015). 2009 ve 2015 y1lı hayat bilgisi dersi öğretim programlarının karşılaştırılması. Bayburt Üniversitesi Eğitim Fakültesi Dergisi, 10(2), 341-374. http://dx.doi.org/10.24315/tred.520314

Thoe, N. K. \& Lin, C. S. (2006). Integrating 'Learning Together' with out door science activities. Learning Scince\&Mathematics, (October, 1). [Online]: Retrived on 14-January-.2008, at URL: http://www.recsam.edu.my/html/onlineJ.html.

Tıraş, H. H. (2012). Sürdürülebilir kalkınma ve çevre: Teorik bir inceleme. Kahramanmaraş Sütţü İmam Üniversitesi İktisadi ve İdari Bilimler Fakültesi Dergisi, 2(2), 57-73.

Tilbury, D. (1995). Environmental education for sustainability: Defining the new focus of environmental education in the 1990s. Environmental Education Research, 1(2), 195-212. https:doi.org/10.1080/1350462950010206

Topkaya, Y. \& Doğan, Y. (2020). The effect of educational comics on teaching environmental 1ssues and environmental organizations topics in 7th grade social studies course: a mixed research. Education and Science, 45(201) 167-188. https:doi.org/10.15390/EB.2019.8575

Topkaya, Y. \& Şimşek, U. (2015). Impact of instructional comics on the attitudes towards citizenship and democracy education. Journal of Computer and Education Research, 3(6), 152-167. https:doi.org/10.18009/jcer.26543

Topkaya, Y. (2014). Vatandaşlık ve demokrasi eğitimi dersinde çizgi roman kullanımının bilişsel ve duyuşsal öğrenmelere etkisi. [Yayımlanmamış Doktora Tezi]. Atatürk Üniversitesi Eğitim Bilimleri Enstitüsü.

Topkaya, Y. (2016). The impact of instructional comics on the cognitive and affective learning about environmental problems. Education and Science, 4l(187), 199-219. https:doi.org/10.15390/EB.2016.5713

Türkiye Erozyonla Mücadele Ağaçlandırma ve Doğal Varlıkları Koruma Vakfı (TEMA). (2020). http://www.tema.org.tr/web_14966-2_1/neuralnetwork.aspx?type=60, Erişim Tarihi: 29.05 .2020

Türküm, A., S. (1998). Çağdaş toplumda çevre sorunları ve çevre bilinci. Anadolu Üniversitesi Açık Öğretim Fakültesi Çăgdaş Yaşam Çăgdaş İnsan Dergisi, 165-181.

United Nations (UN). (1987). Report of the World Commission on Environment and Development: Our Common Future. http://www.un-documents.net/wced-ocf.htm. UN. World Charter for Nature. http://www.un.org/documents/ga/res/37/a37r007.htm. 
United Nations Educational Scientificand Cultural Organization (UNESCO). (2014). Education for sustainable Development

(ESD). [Online]:www.unesco.org/new/en/education/themes/leading-theinternationalagenda/education-for-sustainable-development/.

Uzun, N. \& Sağlam, N. (2007). Ortaöğretim öğrencilerinin çevreye yönelik bilgi ve tutumlarına "çevre ve insan" dersi ile gönüllü çevre kuruluşlarının etkisi. Hacettepe Üniversitesi Eğitim Fakültesi Dergisi,33(33), 210-218.

Ünal, O. (2018). Sosyal bilgiler dersinde eğitici çizgi roman kullanımının ögrenci başarısı ve tutumuna etkisi. [Yayımlanmamış Yüksek Lisans Tezi]. Akdeniz Üniversitesi Eğitim Bilimleri Enstitüsü.

Ünal, S. \& Dımışkı, E. (1999). UNESCO-UNEP himayesinde çevre eğitiminin gelişimi ve Türkiye'de ortaöğretim çevre eğitimi. Hacettepe Üniversitesi Ĕgitim Fakültesi Dergisi, (1617): 142-154.

www.keskkonnaharidus.ee, 2019, Erişim Tarihi: 18.09.2019.

Yeşilyurt, F. (2018). Öğretmen adaylarının çevre risk algısının belirlenmesi. [Yayınlanmamış Yüksek Lisans Tezi]. Amasya Üniversitesi Fen Bilimleri Enstitüsü.

Yıldırım, A. \& Şimşek, H. (2000). Sosyal bilimlerde nitel araştırma yöntemleri. Seçkin Yayıncılık.

Yıldırım, A. (1996). Disiplinler arası öğretim kavramı ve programlar açısından doğurduğu sonuçlar. Hacettepe Üniversitesi Ë̆itim Fakültesi Dergisi, 12, 89-94.

Yılmaz, A., Morgil, F., Aktuğ, P. \& Göbekli, İ. (2002). Ortaöğretim ve üniversite öğrencilerinin çevre, çevre kavramları ve sorunları konusundaki bilgileri ve öneriler. Hacettepe Üniversitesi Eğitim Fakültesi Dergisi, 22(22).

Yılmaz, İ. (2016). Türkiye'de ilkokul programlarında çevre ĕgitimi ve ilkokul 4. sınıf ögrencilerinin Tiflis Konferansı çevre eğitimi amaçlarına ulaşma düzeyi. [Yayınlanmamış Yükssek Lisans Tezi]. Trakya Üniversitesi Sosyal Bilimler Enstitüsü. 